\title{
Reproductive Health Risks Associated with Occupational and Environmental Exposure to Pesticides
}

\author{
Aleksandra Fucic ${ }^{1, *}$, Radu C. Duca ${ }^{2,3}{ }^{\mathbb{D}}$, Karen S. Galea ${ }^{4} \mathbb{D}^{\text {, Tihana Maric }}{ }^{5}$, Kelly Garcia ${ }^{6}$, Michael S. Bloom ${ }^{6} \mathbb{D}$, \\ Helle R. Andersen 7 (iD and John E. Vena ${ }^{8}$
}

1 Institute for Medical Research and Occupational Health, 10000 Zagreb, Croatia

2 Unit Environmental Hygiene and Human Biological Monitoring, Department of Health Protection, National Health Laboratory, L-3555 Dudelange, Luxembourg; Radu.DUCA@lns.etat.lu

3 Centre for Environment and Health, KU Leuven, 3001 Leuven, Belgium

4 Institute of Occupational Medicine, Edinburgh EH14 4AP, UK; karen.Galea@iom-world.org

5 Medical School, University of Zagreb, 10000 Zagreb, Croatia; tihana.maric@mef.hr

6 Department of Global and Community Health, George Mason University, Fairfax, VA 22030, USA; kgarcia6@gmu.edu (K.G.); mbloom22@gmu.edu (M.S.B.)

7 Department of Public Health, University of Southern Denmark, DK-5000 Odense C, Denmark; HRAndersen@health.sdu.dk

8 Department of Public Health Sciences, Medical University of South Carolina, Charleston, SC 29425, USA; Vena@musc.edu

* Correspondence: afucic@imi.hr; Tel.: +385-15682500; Fax: +3814673303

check for updates

Citation: Fucic, A.; Duca, R.C.; Galea, K.S.; Maric, T.; Garcia, K.; Bloom, M.S.; Andersen, H.R.; Vena, J.E. Reproductive Health Risks Associated with Occupational and Environmental Exposure to Pesticides. Int. J. Environ. Res. Public Health 2021, 18, 6576. https:// doi.org/10.3390/ijerph18126576

Academic Editor: Jun Yoshinaga

Received: 20 April 2021

Accepted: 14 June 2021

Published: 18 June 2021

Publisher's Note: MDPI stays neutral with regard to jurisdictional claims in published maps and institutional affiliations.

Copyright: (c) 2021 by the authors. Licensee MDPI, Basel, Switzerland. This article is an open access article distributed under the terms and conditions of the Creative Commons Attribution (CC BY) license (https:/ / creativecommons.org/licenses/by/ $4.0 /)$.
Abstract: A marked reduction in fertility and an increase in adverse reproductive outcomes during the last few decades have been associated with occupational and environmental chemical exposures. Exposure to different types of pesticides may increase the risks of chronic diseases, such as diabetes, cancer, and neurodegenerative disease, but also of reduced fertility and birth defects. Both occupational and environmental exposures to pesticides are important, as many are endocrine disruptors, which means that even very low-dose exposure levels may have measurable biological effects. The aim of this review was to summarize the knowledge collected between 2000 and 2020, to highlight new findings, and to further interpret the mechanisms that may associate pesticides with infertility, abnormal sexual maturation, and pregnancy complications associated with occupational, environmental and transplacental exposures. A summary of current pesticide production and usage legislation is also included in order to elucidate the potential impact on exposure profile differences between countries, which may inform prevention measures. Recommendations for the medical surveillance of occupationally exposed populations, which should be facilitated by the biomonitoring of reduced fertility, is also discussed.

Keywords: male; female; infertility; transplacental

\section{Introduction}

Many studies have investigated the effects of pesticides on male and female fertility. Similar to other agents present in the environment, exposure to pesticides may occur in occupational settings, through water consumption and dietary exposures, and from agricultural or gardening activities. Additionally, exposure may occur in populations residing next to crop and other agricultural fields, via sprayed pesticides spread by wind. The duration and timing of exposure to pesticides is likely to play a significant role in the severity of associated fertility disturbances [1].

Global pesticide use has increased over the past 30 years, with approximately 4 million tons of active ingredients consistently applied annually in recent years (FAOSTAT, 2020, http:/ / www.fao.org/faostat/en/\#data/RP/visualize last accessed on 13 April 2021). The United Nations Food and Agricultural Organization (http: / / www.fao.org/agriculture/ crops/obsolete-pesticides/why-problem/pesticide-bans/en/, accessed on 19 April 2021) 
suggests that more than $20 \%$ of obsolete pesticide stockpiles consist of persistent organic pollutants (POPs), with some stockpiled pesticides being nearly 30 years old. They also suggest that there are instances where highly hazardous pesticides, which are not permitted for use in industrialized countries, are exported to developing countries [2].

The Pesticide Action Network International (PAN) reports that one or more of the 162 countries included in their consolidated list have banned a total of 460 active pesticide ingredients or groups of active ingredients regarded as "currently in use" in the global market, i.e., not considered to be obsolete (2021, PAN, 5th Edition, March 2021. Available from http:/ / pan-international.org/pan-international-consolidated-list-of-bannedpesticides /, last accessed on 19 March 2021). The EU and UK were noted as the polities with the most known bans, with 175 banned and 208 specifically "not approved" pesticides, which are Highly Hazardous Pesticides according to their criteria. Switzerland $(n=140)$, Brazil $(n=131)$, Egypt $(n=76)$, Saudi Arabia $(n=73)$, Indonesia $(n=61)$, Cambodia $(n=60)$, India $(n=55)$, Mauritania $(n=52)$, Palestine $(n=52)$ and China $(n=51)$ were also highlighted as having high numbers of banned pesticides [3].

In 2019, Donley highlighted that whilst the PAN database is comprehensive and updated regularly, it does not include complete pesticide status data for the US, and it does not separate voluntary pesticide cancellation from non-voluntary cancellation in the US and EU [4]. The Rain Forest Alliance UTZ certification program developed a list of banned pesticides and a pesticides watchlist in 2015 (2015 UTZ list of banned pesticides and pesticides watch list. Version 1. Available from https://utz.org/?attachment_id= 3272, accessed on 23 March 2021). The pesticides listed as reproductive toxicants are as follows: azafenidin, benomyl, borax, disodium tetraborate decahydrate, boric acid, dinocap, dinoterb, ethylene thiourea, fluazifop-butyl, flumioxazin, flusilazole, linuron, nitrobenzene, silafluofen, tridemorph, vinclozolin and warfarin [5].

Pesticides, including legacy organochlorine pesticides (OCPs), such as dichlorodiphenyltrichloroethane (DDT), hexachlorobenzene (HCB), and chlordane, as well as contemporary organophosphate-based agents, pyrethroids, triazines and others, may have a deleterious impact on human fertility. Thus, the International Federation of Gynecology and Obstetrics (FIGO) [6], the American College of Obstetrics and Gynecology (ACOG), and the American Society for Reproductive Medicine (ASRM) [7] have called for greater attention to accumulating evidence that non-occupational, or "background", exposures to environmental pollutants, including pesticides, may be reproductive toxicants. At high doses, experimental evidence suggests that pesticide exposure modifies endocrine function, disrupting gonadotropin, thyroid, and sex-steroid hormone signaling [8,9], and induces oxidative stress $[10,11]$, altering sexual development, fecundity and maintenance of pregnancy. However, human data remain controversial as regards the lower background levels of environmental pollutants, including pesticides, to which much of the general population is exposed continuously [12-15].

As the western world has faced a significant reduction in fertility during the last few decades [16-19], the aim of this comprehensive review is to update current knowledge on the association between environmental and occupational exposure to pesticides and fertility disturbances in men and women, although without estimating associations or assessing evidence of causality. This review also includes reproductive health risks after exposures to pesticides across the life-span, from intrauterine development, to childhood, to adulthood.

\section{Material and Methods}

Published studies to be included in this review were required to fulfill the following criteria: (a) full length papers reporting original data in a peer-reviewed journal; (b) selfreporting exposure and/or measured levels of metabolites in blood or urine; (c) minimum of 20 subjects and a corresponding referent group; (d) English language, and (e) published between and including the years 2000 and 2020. We also consulted relevant reviews. At all stages of the review process (title, abstract and full text), those articles considered to 
not fulfil the inclusion criteria were excluded. One case report and one commentary were excluded. The literature databases PubMed and Scopus were searched using the following search terms and strings:

infertility + pesticide + exposure, abortion + pesticide + exposure; IVF + pesticide + exposure; pregnancy + pesticide + exposure, ovulation + woman + pesticides, and menarche + pesticides for female fertility; and sperm + pesticide + exposure and sperm + morphology + pesticide; pesticide(s) OR active ingredient + banned + withdrawn; pesticide + sperm; pesticide + transplacental; pesticide + intrauterine; pesticide + prenatal exposure + testosterone; prenatal + pesticide + exposure + infertility; prenatal + pesticide + exposure + semen; prenatal + fungicide + exposure + newborn; in utero + pesticide + newborn; in utero + pesticide + testosterone; in utero + pesticide + fertility; in utero + pesticide + estradiol; in utero + pesticide + semen; in utero + pesticide + puberty

A schematic presentation of the scheme reporting the literature retrieval and selection strategy is shown in Figure 1.

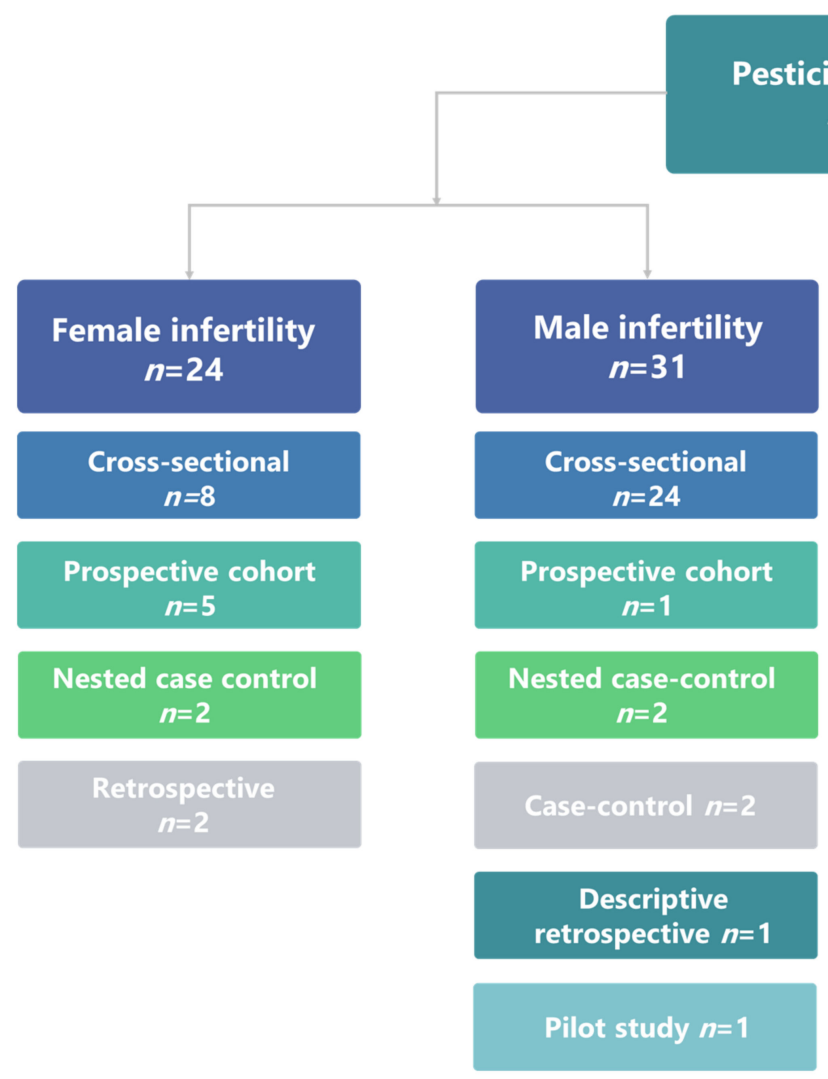

Figure 1. Graphical presentation of selected papers included in review article.

After the searches were complete, the titles and, where available, abstracts were screened by section authors to identify studies of relevance in accordance with the inclusion criteria. A conservative strategy was adopted, in which all potentially relevant citations were retained for full-text scanning. Following the screening of the titles and abstracts, copies of full papers were obtained for full reviewing. At least two authors read the full text of the selected papers for each section. After consensus was derived on the interpretation of the results, each author contributed to manuscript preparation.

Figure 1 gives insight into the numbers and types of papers included. The selection process resulted in a total of 107 articles, which were used in our review of associations between fertility outcomes, occupational, environmental, and transplacental exposure to pesticides, and age- or sex-specific susceptibility. 
The quality of the included articles was not individually assessed. This review focused on describing recent advances and summarizing fertility, sexual maturation and pregnancy complications associated with occupational, environmental and transplacental exposures to pesticides, rather than a formal review of the study quality or possible bias in the included epidemiological studies [20].

\section{Results}

\subsection{Female Fertility}

The quantitative results of studies and the associated statistical significance are reported in Table 1.

\subsubsection{Time to Pregnancy and Infertility}

The ability to conceive a pregnancy is frequently measured as time to pregnancy (TTP), which is the number of menstrual cycles with unprotected heterosexual intercourse to conceive a pregnancy without assistance [21,22]. TTP is often expressed as fecundability odds ratio (FOR), the conditional odds for conceiving in a given cycle (i.e., month), or as clinical infertility, which is more than 12 months of trying without a pregnancy [23].

Environmental Exposures

Studies Using Direct Exposure Assessment/Biomonitoring Strategies

In a retrospective study from Sweden, 22 POPs, including 9 OCPs and 12 nonpesticide polychlorinated biphenyls (PCBs), were measured in 1st trimester blood specimens ( 10 weeks gestation) from 818 women with pregnancies in 2007-2010, and these were related to self-reported TTP [24]. The women were 18-43 years old. There was no association of individual serum OCPs with TTP, although 3rd quartile serum hexachlorobenzene (HCB) was associated with greater odds of infertility, adjusted for confounding. However, greater serum HCB was associated with longer TTP among younger women (<29 years) who had used combined oral contraceptives (COCs). In contrast, the 2nd and 4th quartiles of dichlorodiphenyldichloroethylene ( $\mathrm{p}, \mathrm{p}^{\prime}$-DDE), a persistent metabolite of DDT, were associated with longer TTP among older women ( $\geq 29$ years) who had used COCs. To accommodate strong pairwise correlations, the authors implemented weighted quantile sum regression, an approach that allows one to estimate a single weighted exposure index of all 22 measured POPs [25]. Although greater overall POP exposure was associated with longer TTP among older women without use of COCs, important associations were limited to PCBs and no OCPs were identified as important. However, each quartile of overall POP exposure was also associated with greater odds of infertility among older women without the use of COCs, and $8.0 \%$ of the association was attributed to trans-nonachlor, a persistent lipophilic component of chlordane.

In a prospective study from China, six organophosphate (OP) and three pyrethroid pesticide metabolites were measured in preconception urine from 615 women 24-44 years of age from the general population in 2013-2015 [26]. Women were followed prospectively until 12 months of trying or a pregnancy, including the time spent trying to conceive before study enrollment. Women in the highest quartile of urinary diethylthiophosphate (DETP) level, an OP insecticide metabolite, had longer TTP and greater odds of infertility than women in the lowest quartile of urinary DETP adjusted for confounding although without a linear trend. Women in the 4th quartile of urinary 3-phenoxybenzoic acid (3-PBA), a pyrethroid insecticide metabolite, also had longer TTP and greater infertility rates than women in the 1st quartile.

Studies Using Indirect Exposure Assessment Strategies

A retrospective cohort investigation from Colombia found little evidence of an association between self-reported TTP, measured among 2592 women 15-54 years of age with a pregnancy in the past five years, and glyphosate exposure assigned to residential region in 2004-2005 [27]. Women residing in some areas with aerial glyphosate spraying programs had longer TTPs than women residing in a reference region without glyphosate spraying. However, residence in other regions without aerial glyphosate spraying were 
also associated with longer TTP, and there was no TTP difference between additional regions with and without glyphosate use.

\subsubsection{Assisted Reproduction}

Women using assisted reproductive technologies, such as in vitro fertilization (IVF), are distinct in terms of the intensity of data collection and follow-up, presenting an unprecedented opportunity to observe early pregnancy events that are the critical, but usually unobserved, determinants of live birth, such as oocyte and embryo development [28]. These populations offer opportunities for disentangling "critical windows" of biologic vulnerability for infertility that are infeasible in populations conceiving spontaneously, including the collection of highly invasive biospecimens, such as ovarian follicular fluid. A recent narrative review suggested deleterious impacts on oocyte maturation, oocyte fertilization, embryo development, and ultimately live births associated with pesticide exposure [29].

Environmental Exposure

Studies Using Direct Exposure Assessment/Biomonitoring Strategies

A nested case-control study of three US infertility clinics measured serum HCB, $\mathrm{p}, \mathrm{p}^{\prime}$-DDE, $\mathrm{o}, \mathrm{p}^{\prime}$-DDE, $\mathrm{p}, \mathrm{p}^{\prime}$-DDT and $\mathrm{o}, \mathrm{p}^{\prime}$-DDT in association with IVF outcomes among 720 women with a mean (SD) age of 35.4 years (4.20) in 1994-2003 [30]. The serum OCPs positively correlated with measures in ovarian follicular fluid [31]. The authors reported a higher probability of a negative pregnancy test after embryo transfer among women with pre-cycle serum $\mathrm{HCB}$ in the 2 nd quartile relative to the 1 st quartile. Importantly, serum HCB levels were lower than those reported for US females in general. However, no association was detected with clinical pregnancy, or with serum DDE or DDT concentrations.

A small prospective investigation of 32 women, 28-42 years old, undergoing IVF at another US infertility clinic measured 45 POPs, including 43 PCBs, p, p'-DDT and p, p'-DDE, in ovarian follicular fluid [32]. DDE was detected in all follicular fluid specimens and both DDE and DDT were significantly higher among Asian women than white women. Greater DDE was associated with a lower probability to receive a mature oocyte, although a greater likelihood for live birth and DDT was associated with higher peak-estradiol.

Studies Using Indirect Exposure Assessment Strategies

A prospective investigation of 325 women undergoing treatment at a US infertility clinic, primarily IVF, reported lower likelihoods for pregnancy and live birth in association with greater consumption of high-pesticide residue fruits and vegetables, as reported on a study questionnaire taken in 2007-2016. The women were 18-45 years of age. The authors used the 2006-2015 Department of Agriculture Pesticide Data Program mean pesticide residue data to categorize reported foods as high-pesticide and low-pesticide residue items. Women in the highest quartile of high-pesticide fruit and vegetable consumption were significantly less likely to have a clinical pregnancy and a live birth than women in the lowest quartile of high-pesticide fruit and vegetable consumption. However, there was no association detected for consumption of low-pesticide residue fruits and vegetables [33].

\subsubsection{Ovarian Reserve and Hormone Levels}

Environmental Exposure

Studies Using Direct Exposure Assessment/Biomonitoring Strategies

Jurewicz et al. in 2020 studied exposure to pyrethroid pesticides and ovarian reserve in 511 females, aged 25-39 years, attending an infertility clinic in Poland [34]. Greater urinary concentrations of 3-PBA were associated with decreased antral follicle count $(p=0.02)$ and levels of anti-mullerian hormone (AMH) $(p=0.03)$ and increased follicle-stimulating hormone (FSH) $(p=0.04)$. The authors concluded that synthetic pyrethroids may affect female ovarian reserve.

Studies Using Indirect Exposure Assessment Strategies

Whitworth et al. (2015) studied AMH in relation to indoor, primarily seasonal, DDT and pyrethroid spraying for malaria prevention among women 20-30 years of age in eight rural South African villages [35]. Women who reported indoor residual pyrethroid spray- 
ing had 25\% lower AMH concentrations compared with women who reported no spraying, although there was only limited evidence for associations with DDT spraying. Prior reviews have suggested links between pesticide exposure and ovarian toxicity leading to female infertility, including premature ovarian insufficiency (POI) and polycystic ovary syndrome (PCOS), menstrual problems and altered sex steroid hormone synthesis [29,36-39], although the effects were likely dose-dependent and agent specific [40], and varied with the timing of the exposure [41].

\subsubsection{Spontaneous Fetal Loss (Miscarriage)}

Occupational Exposure

Studies Using Indirect Exposure Assessment Strategies

Garry et al. studied exposures to pesticides and risk of pregnancy loss in US applicators (98\% men) and their spouses (women) [42]. Women were 15 to $>35$ years of age at the time of pregnancy. Among the 695 participants, there was a modest but significant increase in risk (1.6-fold to 2-fold) of miscarriages and/or fetal loss occurring throughout the year in the spouses of applicators who used fungicides, with the greatest risks during pesticide application in spring. Women using pesticides experienced a greater risk for miscarriage as did women whose male partner used pesticides containing sulfonylurea, imidizoline, and a mixture of chlorophenoxy, sulfonylurea, and benozothiodiazole.

Naidoo et al. [43] examined cross-sectional associations of pesticide exposure with spontaneous miscarriage among 911 women 18-82 years of age, working in two distinct South African agricultural areas (i.e., the irrigation scheme and drylands). Spraying pesticides during the first three months of a pregnancy was associated with a greater prevalence of spontaneous miscarriage. Older ( $\geq 40$ years of age) irrigation scheme women were more likely to report spontaneous miscarriage than younger women. An important limitation was that exposure was assessed by occupational history only.

Rahimi et al. interviewed women working in greenhouses and married for at least one year, with 338 unexposed controls from nearby villages, in a cross-sectional study from southern Iran [44]. The women were 16-49 years of age. The greenhouse workers had a significantly $(p=0.002)$ greater number of spontaneous pregnancy losses before 20 weeks completed gestation $($ mean $=0.26)$ than the control women $($ mean $=0.18)$, although this is unadjusted for confounding factors or number of pregnancies.

\subsubsection{Age at Menarche}

Occupational Exposure

Studies Using Direct Exposure Assessment/Biomonitoring Strategies

In a study on 151 female offspring of US anglers 20-50 years of age, each $15 \mathrm{ug} / \mathrm{L}$ increase in back-extrapolated gestational DDE exposure was associated with one year earlier menarche $(p=0,04)$, adjusted for confounders [45]. However, the association became non-significant when controlling for estimated body size at menarche among a subsample of $n=102$.

Environmental Exposure

Studies Using Direct Exposure Assessment/Biomonitoring Strategies

A cross-sectional analysis of 305 girls aged 9-15 years old from Hangzhou, China, found that pyrethroid exposure may be associated with a greater prevalence of delayed pubertal onset [46]. This study analyzed urinary 3-PBA at the time of the interview, and this was detected in $89 \%$ of the participants. Using self-assessed Tanner stages, pubertal onset by the odds of breast stage 3, pubic hair stage 2 and self-reported menarche were associated with a greater urinary 3-PBA level.

A cross-sectional analysis of nulliparous and newly married Chinese women, 20-34 years of age, showed an earlier self-reported age at menarche in association with higher serum DDT concentrations [47]. Relative to those in the lowest DDT quartile, the adjusted mean age of menarche was approximately 1.11 years younger among those in the fourth quartile, with a significant linear trend. 
A nested case-control study found a weak, non-significant association of in utero exposure with the atrazine metabolite diaminochlorotriazine (DACT), measured in gestational maternal urine specimens (median $=12$ weeks), and with early menarche [48]. The study was conducted within a larger prospective cohort, in which the offspring of 14,775 women were mailed an annual health questionnaire from 8 to 17 years of age. Maternal exposure was collected for 174 cases of early menarche (<ll.5 years of age) and 195 controls ( $>11.5$ years of age). DACT was found to be the most frequently detected analyte (58\% above LOD). This association became statistically significant in a subset of $n=85$ that excluded girls with missing data.

\subsubsection{Menstrual Cycle Length}

Environmental Exposure

Studies Using Direct Exposure Assessment/Biomonitoring Strategies

In a prospective cohort, the relationship between a mixture of POPs, menstrual cycle length and duration of bleeding among women who are attempting to become pregnant was investigated [49]. Select POPs were found to be associated with differences in menstruation. Women aged 18-44 years were recruited from a larger angler cohort study, residing in counties along Lakes Erie and Ontario. Eighty-three participants contributing to 447 cycles for analysis provided a blood sample at enrollment for the quantification of 76 PCBs and seven OCPs. A statistically significant three-day increase in cycle length was observed for women in the highest tertile of estrogenic PCBs relative to the lowest tertile. A significant reduction in bleeding (less than one day) was seen among women in the highest versus the lowest tertile of aromatic fungicide exposure.

In the aforementioned cross-sectional study of 466 newly married, nulliparous Chinese women aged 20-34 years [47], women in the fourth quartile for serum DDT (range: $41.6-113 \mathrm{ng} / \mathrm{g}$; mean $=57.1 \mathrm{ng} / \mathrm{g}$ ) exposure had 2.78 times higher odds of experiencing a short menstrual cycle (defined as $\leq 21$ days) in the previous year relative to those in the lowest DDT quartile (range: $5.52-19.2 \mathrm{ng} / \mathrm{g}$; mean = $13.5 \mathrm{ng} / \mathrm{g}$ ). These odds became even stronger after the exclusion of women who drank alcohol, used oral contraceptives/intrauterine device (IUD), or who experienced a spontaneous or induced abortion. In contrast, there was no association between DDT and long menstrual cycles.

\subsection{Male Infertility}

Quantitatve results of the studies and the associated statistical significance are reported in Table 2.

Occupational Exposure

Studies Using Indirect Exposure Assessment/Biomonitoring Strategies 
Table 1. Epidemiologic studies estimating associations between pesticide exposure and female fertility.

\begin{tabular}{|c|c|c|c|c|c|c|c|}
\hline Study & Site & Design & Exposure & $\begin{array}{l}\text { Duration of } \\
\text { Exposure }\end{array}$ & Sample & Outcome & Results \\
\hline Björvang et al., 2020 [24] & $\begin{array}{l}\text { Sweden } \\
\text { (environmental } \\
\text { exposure) }\end{array}$ & Cross-sectional & $\begin{array}{c}\text { Serum gestational POPs } \\
\text { (9 OCPs, } 10 \text { PCBs and } \\
3 \text { PBDEs) }\end{array}$ & Long-term & $\begin{array}{c}n=818 \text { women with a } \\
\text { pregnancy }\end{array}$ & $\begin{array}{l}\text { TTP and clinical } \\
\text { infertility }\end{array}$ & $\begin{array}{l}\text { 3rd Q vs. 1st Q HCB associated with: } \\
\text { (1) infertility (OR }=2.25,95 \% \text { CI: } 1.06,4.78) \text {; } \\
\text { (2) longer TTP among women }<29 \text { years of } \\
\text { age who used COCs. DDE associated with } \\
\text { longer TTP among women } \geq 29 \text { years who } \\
\text { used COCs. }\end{array}$ \\
\hline Bloom et al., 2017 [32] & $\begin{array}{l}\text { United States } \\
\text { (environmental } \\
\text { exposure) }\end{array}$ & $\begin{array}{l}\text { Prospective } \\
\text { cohort }\end{array}$ & $\begin{array}{l}\text { Ovarian follicular fluid } \\
\text { organochlorines } \\
\text { (2 OCPs and } 43 \text { PCBs) }\end{array}$ & Long-term & $\begin{array}{c}n=32 \text { women } \\
\text { undergoing IVF }\end{array}$ & $\begin{array}{l}\text { Measures of ovarian } \\
\text { reserve and IVF } \\
\text { outcomes }\end{array}$ & $\begin{array}{c}\text { DDE associated with oocyte maturity } \\
\text { (RR }=0.72 ; 95 \% \text { CI: } 0.60,0.86) \text { and live } \\
\text { birth }(\mathrm{RR}=3.65 ; 95 \% \text { CI: } 1.08,12.31) \text {. DDT } \\
\text { associated with E2 }(\beta=1.45,95 \% \text { CI: } 0.92, \\
1.97)\end{array}$ \\
\hline Chiu et al., 2018 [33] & $\begin{array}{l}\text { United States } \\
\text { (environmental } \\
\text { exposure) }\end{array}$ & $\begin{array}{l}\text { Prospective } \\
\text { cohort }\end{array}$ & $\begin{array}{l}\text { Self-reported } \\
\text { consumption of fruit } \\
\text { and vegetable } \\
\text { pesticide residues }\end{array}$ & $\begin{array}{c}\text { Short-term } \\
\text { (past } 3 \text { months) }\end{array}$ & $\begin{array}{l}n=325 \text { women } \\
\text { undergoing IVF } \\
\text { (541 cycles) }\end{array}$ & $\begin{array}{l}\text { Pregnancy and } \\
\text { live birth }\end{array}$ & $\begin{array}{l}\text { High pesticide residue fruits and } \\
\text { vegetables associated with lower } \\
\text { probabilities for pregnancy }(p=0.04) \text { and } \\
\text { live birth }(p=0.02) .\end{array}$ \\
\hline Garry et al., 2002 [42] & $\begin{array}{l}\text { United States } \\
\text { (Occupational } \\
\text { exposure) }\end{array}$ & Cross-sectional & $\begin{array}{l}\text { Self-reported } \\
\text { application of } \\
\text { herbicides, insecticides, } \\
\text { fungicides and } \\
\text { fumigants }\end{array}$ & $\begin{array}{l}\text { Current and } \\
\text { historic }\end{array}$ & $\begin{array}{l}n=522 \text { women with } \\
\text { singleton pregnancies } \\
\text { fathered by a licensed } \\
\text { pesticide applicator }\end{array}$ & $\begin{array}{l}\text { Pregnancy loss and } \\
\text { menstrual function }\end{array}$ & $\begin{array}{l}\text { Herbicide/insecticide/fungicide use vs. } \\
\text { herbicide only use associated with } \\
\text { pregnancy loss } \\
\quad(\mathrm{OR}=1.64,95 \% \mathrm{CI}: 1.01,2.67)\end{array}$ \\
\hline Hu et al., 2018 [26] & $\begin{array}{l}\text { China } \\
\text { (environmental } \\
\text { exposure) }\end{array}$ & $\begin{array}{l}\text { Prospective } \\
\text { cohort }\end{array}$ & $\begin{array}{c}\text { Urinary } \\
\text { organophosphate (6) } \\
\text { and pyrethroid (3) } \\
\text { metabolites }\end{array}$ & Short-term & $\begin{array}{l}n=615 \text { women } \\
\text { planning a pregnancy }\end{array}$ & $\begin{array}{l}\text { TTP and clinical } \\
\text { infertility }\end{array}$ & $\begin{array}{c}\text { 4th } Q \text { vs. 1st } Q \text { DETP associated with TTP } \\
\text { (FOR = 0.68, 95\%CI: } 0.51,0.92) \text { and } \\
\text { infertility (OR = 2.17, 95\%CI: } 1.19,3.93) \text {; } \\
\text { 4th Q vs. 1st Q 3-PBA associated with TTP } \\
\text { (FOR = 0.72, 95\%CI: 0.53, 0.98) and } \\
\text { infertility (OR = } 2.03,95 \% \text { CI: } 1.10-3.74) \\
\text { in nulliparas. }\end{array}$ \\
\hline Jurewicz et al., 2020 [34] & $\begin{array}{l}\text { Poland } \\
\text { (environmental } \\
\text { exposure) }\end{array}$ & Cross-sectional & $\begin{array}{l}\text { Urinary pyrethroid } \\
\text { metabolites }(4)\end{array}$ & Short-term & $\begin{array}{c}n=511 \text { women } \\
\text { undergoing infertility } \\
\text { evaluation }\end{array}$ & $\begin{array}{c}\text { Measures of } \\
\text { ovarian reserve }\end{array}$ & $\begin{array}{c}\text { 3-PBA associated with AFC }(\beta=-0.02 \\
\text { follicles, } 95 \% \text { CI: }-0.06,-0.01), \text { AMH } \\
(\beta=-0.04 \text { ng/mL, } 95 \% \text { CI: }-0.12,-0.04), \\
\text { FSH ( } \beta=0.01 \mathrm{IU} / \mathrm{L}, 95 \% \mathrm{CI}: 0.01,0.25) \\
\text { per ng/mL. }\end{array}$ \\
\hline Louis et al., 2011 [49] & $\begin{array}{l}\text { United States } \\
\text { (environmental } \\
\text { exposure) }\end{array}$ & $\begin{array}{l}\text { Prospective } \\
\text { cohort }\end{array}$ & $\begin{array}{l}\text { Serum organochlorines } \\
\text { (7 OCPs and } 76 \text { PCBs) }\end{array}$ & Long-term & $\begin{array}{l}n=83 \text { women planning } \\
\text { a pregnancy (447 cycles) }\end{array}$ & Menstrual function & $\begin{array}{c}\text { 3rd T vs. 1st } \mathrm{T} \text { aromatic fungicides } \\
\text { associated with days bleeding } \\
(\beta=-0.15 \text { days, } 95 \% \mathrm{CI}:-0.29,-0.002) \text {. }\end{array}$ \\
\hline
\end{tabular}


Table 1. Cont

\begin{tabular}{|c|c|c|c|c|c|c|c|}
\hline Study & Site & Design & Exposure & $\begin{array}{l}\text { Duration of } \\
\text { Exposure }\end{array}$ & Sample & Outcome & Results \\
\hline Mahalingaiah, 2012 [30] & $\begin{array}{l}\text { United States } \\
\text { (environmental } \\
\text { exposure) }\end{array}$ & $\begin{array}{l}\text { Nested case } \\
\text { control }\end{array}$ & $\begin{array}{l}\text { Serum DDT, DDE } \\
\text { and HCB }\end{array}$ & Long-term & $\begin{array}{l}n=720 \text { women } \\
\text { undergoing IVF } \\
\text { (827 cycles) }\end{array}$ & $\begin{array}{l}\text { Failed implantation, } \\
\text { pregnancy and } \\
\text { pregnancy loss }\end{array}$ & $\begin{array}{l}\text { 4th } Q \text { vs. 1st } Q \text { HCB associated with failed } \\
\text { implantation }(\mathrm{OR}=2.32,95 \% \mathrm{CI}: 1.38,3.90) \text {. }\end{array}$ \\
\hline Naidoo et al., 2011 [43] & $\begin{array}{l}\text { South Africa } \\
\text { (occupational } \\
\text { exposure) }\end{array}$ & Cross-sectional & $\begin{array}{c}\text { Self-reported } \\
\text { pesticide spraying }\end{array}$ & $\begin{array}{l}\text { Short-term } \\
\text { (during early } \\
\text { pregnancy) }\end{array}$ & $\begin{array}{l}n=887 \text { farm workers } \\
\text { with a pregnancy }\end{array}$ & Pregnancy loss & $\begin{array}{c}\text { Spraying pesticides associated with greater } \\
\text { risk of spontaneous loss (OR }=2.6, \\
95 \% \text { CI: } 1.6,6.4) .\end{array}$ \\
\hline Namulanda et al., 2017 [48] & $\begin{array}{c}\text { England } \\
\text { (environmental } \\
\text { exposure) }\end{array}$ & $\begin{array}{l}\text { Nested case } \\
\text { control }\end{array}$ & $\begin{array}{l}\text { Gestational urinary } \\
\text { atrazine } \\
\text { metabolites (6) }\end{array}$ & Short-term & $\begin{array}{c}n=369 \text { girls }(174 \text { cases } \\
195 \text { controls })\end{array}$ & Menarche $(<11.5$ years $)$ & $\begin{array}{l}\text { Diaminochlorotriazine associated with } \\
\text { non-significant odds of early menarche } \\
\quad(\mathrm{OR}=1.13,95 \% \text { CI: } 0.82,1.55) \text {. }\end{array}$ \\
\hline Ouyang et al., 2005 [47] & $\begin{array}{l}\text { China } \\
\text { (environmental } \\
\text { exposure) }\end{array}$ & Cross-sectional & Serum DDT and DDE & Long-term & $\begin{array}{l}n=466 \text { nulliparous } \\
\text { textile workers }\end{array}$ & $\begin{array}{l}\text { Menarche and } \\
\text { menstrual function }\end{array}$ & $\begin{array}{c}\text { DDT associated with: }(1) \text { age at menarche } \\
(-0.20 \text { years, } 95 \% \text { CI: }-0.28, \\
-0.13 \text { per } 10 \mathrm{ng} / \mathrm{g}) ;(2) \text { short menstrual } \\
\text { cycle }(<21 \text { days }) 4 \text { th } Q \text { vs. } 1 \text { st } Q(\mathrm{OR}=2.78, \\
95 \% \mathrm{CI} 1.07,7.14) .\end{array}$ \\
\hline Rahimi et al., 2020 [44] & $\begin{array}{c}\text { Iran } \\
\text { (occupational } \\
\text { exposure) }\end{array}$ & Cross-sectional & $\begin{array}{l}\text { Self-reported } \\
\text { workplace pesticide } \\
\text { exposure }\end{array}$ & $\begin{array}{l}\text { Current and } \\
\text { historic }\end{array}$ & $\begin{array}{c}n=645 \text { women (308 } \\
\text { exposed greenhouse } \\
\text { workers and } 337 \\
\text { unexposed housewives) }\end{array}$ & $\begin{array}{l}\text { Pregnancy loss and } \\
\text { infertility }\end{array}$ & $\begin{array}{c}\text { Greenhouse workers had significantly } \\
\text { greater prevalence of spontaneous loss } \\
(p=0.019) \text { and infertility }(p=0.003) \\
\text { than housewives. }\end{array}$ \\
\hline Vasiliu et al., 2004 [45] & $\begin{array}{l}\text { United States } \\
\text { (environmental } \\
\text { exposure) }\end{array}$ & $\begin{array}{l}\text { Retrospective } \\
\text { cohort }\end{array}$ & $\begin{array}{l}\text { Back extrapolated } \\
\text { pregnancy serum } \\
\text { DDE and PCBs }\end{array}$ & Long-term & $\begin{array}{l}n=151 \text { daughters of } \\
\text { Lake Michigan anglers }\end{array}$ & $\begin{array}{l}\text { Menarche and } \\
\text { menstrual cycle }\end{array}$ & $\begin{array}{c}\text { Extrapolated gestational DDE associated } \\
\text { with age at menarche }(\beta=-0.07 \text { years; } \\
\qquad p=0.038 \text { per } \mu \mathrm{g} / \mathrm{L}) .\end{array}$ \\
\hline Whitworth et al., 2015 [35] & $\begin{array}{l}\text { South Africa } \\
\text { (environmental } \\
\text { exposure) }\end{array}$ & $\begin{array}{l}\text { Prospective } \\
\text { cohort }\end{array}$ & $\begin{array}{l}\text { Plasma DDT and } \\
\text { DDE and indoor } \\
\text { pesticide spraying }\end{array}$ & $\begin{array}{l}\text { Short-term } \\
\text { (seasonal) }\end{array}$ & $\begin{array}{l}n= \\
\quad 420 \text { women from } \\
\text { rural villages }\end{array}$ & Plasma AMH & $\begin{array}{l}\text { Indoor pyrethroid spraying vs. no indoor } \\
\text { spraying associated with AMH (-25\%, } \\
95 \% \text { CI: }-39 \%,-8 \%) .\end{array}$ \\
\hline Ye et al., 2017 [46] & $\begin{array}{l}\text { China } \\
\text { (environmental } \\
\text { exposure) }\end{array}$ & Cross-sectional & $\begin{array}{l}\text { Urinary 3-PBA (a } \\
\text { pyrethroid } \\
\text { metabolite) }\end{array}$ & Short-term & $\begin{array}{c}n=305 \text { girls }(9-15 \\
\text { years of age })\end{array}$ & $\begin{array}{l}\text { Self-assessed (with } \\
\text { mother) sexual } \\
\text { development (Tanner } \\
\text { stages) }\end{array}$ & $\begin{array}{l}\text { 3-PBA associated with breast stage } 3 \\
(\mathrm{OR}=0.55,95 \% \mathrm{CI}: 0.31,0.98) \text {, pubic hair } \\
\text { stage } 2(\mathrm{OR}=0.56,95 \% \mathrm{CI}: 0.36,0.98) \text { and } \\
\text { menarche (OR }=0.51,95 \% \mathrm{CI}: 0.28,0.93) .\end{array}$ \\
\hline
\end{tabular}

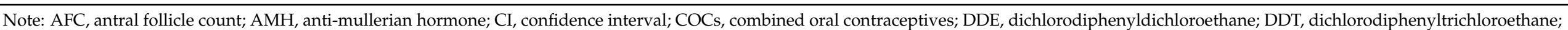

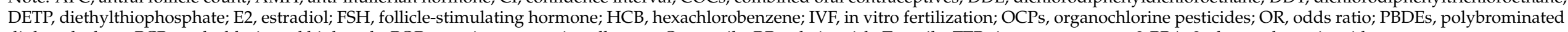

diphenyl ethers; PCBs, polychlorinated biphenyls; POPs, persistent organic pollutants; Q, quartile; RR, relative risk; T, tertile; TTP, time to pregnancy; 3-PBA, 3-phenoxybenzoic acid. 
Occupational exposure to pesticides has been well-documented in several farm communities across the globe. A ten-year retrospective study of Cameroonian men seeking urology services showed that patients older than 50 years and farmers were the most susceptible to poorer semen quality. The researchers believed that this was due to higher pesticide exposure, which was not directly measured in the study, combined with high temperature [50]. Sperm analysis from farmers in Myanmar, who were occupationally exposed to different types of pesticides on a daily basis, showed decreased sperm counts during the growing period compared to non-growing periods. In the growing period, farmers were actively exposed to OP pesticides. Moreover, in the growing period, reproductive hormone levels differed significantly from levels measured in the non-growing period. It is important to stress that in this region men started working as farmers almost immediately after primary school and did not regularly wear protective equipment [51]. African researchers stated that the decreasing sperm count in African men may have been due to exposure to pesticides, especially dibromochloropropane among farmers in the late 1970s [52]. Iranian researchers also observed that farmworkers had a higher prevalence of primary male infertility than the general population, possibly due to their recurrent exposure to pesticides [53]. Young men from rural regions of Brazil also showed poorer sperm quality than men from the urban parts of the country. There was a lower percentage of normal sperm morphology in men using pesticides over longer period, along with higher sperm counts and lower LH levels. On the other hand, this study also showed that larger testicular volumes and longer anogenital distances were associated with maternal farming during pregnancy [54]. Farm worker exposure to pesticides that have been banned or strictly controlled in developed countries remains a concern in Venezuela. Pesticideexposed farmers in Venezuela had a higher DNA fragmentation index and lower sperm quality than unexposed farmers, while $44 \%$ of the subjects had increased LH [55]. Another study showed lower semen volume, sperm motility, normal morphology percentage, seminal zinc concentration as well as testosterone and LH in men who were pesticide applicators. On the other hand, seminal $\mathrm{pH}$, time of liquefaction, percentage of immature sperm and leukocyte concentration were higher in the same group compared to men who were not pesticide applicators. In this study, specific OP metabolites were not correlated with parameters of semen quality [56]. According to these studies, farm workers from rural regions are a group that are critically exposed to pesticides, and therefore the group with highest pesticide impact on infertility. Additionally, men from rural areas may exhibit disrupted quality of sperm parameters and lower serum testosterone and $\mathrm{LH}$, which can potentially correlate with exposure to pesticides [57].

Studies Using Direct Exposure Assessment/Biomonitoring Strategies

The urinary metabolites of OPs were also tested in occupationally exposed Peruvian men through sprayer applicator usage. Decreased seminal plasma volume and increased $\mathrm{pH}$ were associated with higher levels of OP metabolites. More importantly, the exposure level and time of the exposure together showed a more profound effect on sperm quality [58]. Abamectin (ABM), used by Turkish farmers, was also correlated with lower sperm quality. Levels of ABM, measured in farmers' plasma, were relatively high compared to a control group of men. Furthermore, the exposed farm workers had significantly decreased sperm motility and impaired sperm maturity markers, observed by measuring hyaluronic acid sperm binding, as well as higher percentages of aniline blue sperm and increased creatinine kinase-positive sperm [59]. Among male floriculture workers in Mexico, urinary concentrations of OPs were associated with increased serum concentrations of FSH and prolactin, and with decreased serum testosterone and inhibin B [60].

Environmental Exposure

Studies Using Direct Exposure Assessment/Biomonitoring Strategies

A recent study of reproductive-aged Chinese men associated pyrethroid metabolites in urine with semen quality. They found negative associations between 3-PBA and sperm morphology, as well as for trans-3-(2,2-Dichlorovinyl)-2,2-dimethylcyclopropane carboxylic acid (t-DCCA) levels and total sperm count [61]. Another study on non-occupational 
exposure to pyrethroids among Chinese men also showed significant correlations between higher quartiles of 3-PBA levels in urine and sperm concentration, motility and DNA integrity [62]. Urine samples from a healthy Japanese student population contained 3-PBA in $91 \%$ of the subjects, but a correlation with reproductive hormone levels was absent. Likewise, 3-PBA was not associated with semen quality in the same group of men $[63,64]$. These Japanese and Chinese studies reported contradictory results regarding correlations between similar 3-PBA urinary levels and semen quality; the main differences in the studies were the study groups-healthy students in the Japanese study and infertility patients in the Chinese study. Another study of Japanese men attending a fertility clinic showed that pyrethroid metabolites and dietary habits combined were associated with poorer sperm quality, with 3-PBA correlated with lower sperm motility [65]. Moreover, a Polish study on urinary metabolites of pyrethroids had similar outcomes as the Chinese study, also reporting an association between urinary pyrethroid metabolites and semen quality among men attending an infertility clinic. Abnormal sperm morphology was associated with higher levels of cis-3-(2,2-Dichlorovinyl)-2,2-dimethylcyclopropane carboxylic acid (c-DCCA), t-DCCA, and the sum of pyrethroid metabolites, while lower sperm concentration and testosterone levels were associated with t-DCCA [66]. A study by Meeker et al. also suggested an association between urinary 3-PBA and t-DCCA and sperm concentration, while c-DCCA and 3-PBA were associated with increased DNA damage [67]. Furthermore, men with higher c-DCCA and t-DCCA levels in urine had increased sex chromosome disomies compared to men with lower urinary levels. 3-PBA was also related to an increased risk of YY disomies. The mechanism behind these findings is not fully understood. Pyrethroid metabolites are rapidly excreted, but long-term exposure might negatively affect spermatogenesis and meiosis [68].

Pant et al. measured concentrations of POPs, specifically $\mathrm{p}, \mathrm{p}^{\prime}$-DDE and lindane, in semen. Decreased semen quality and higher ROS production were correlated with seminal $p$, $p^{\prime}$-DDE and lindane [69]. The serum of male partners in subfertile couples was analyzed for PCBs and p, $\mathrm{p}^{\prime}$-DDE in another study [70]. There was a negative dose-response relationship between PCB-138 and sperm concentration, motility and morphology; however, an association of sperm parameters and other PCBs with p, p'-DDE was not detected [70]. Norwegian researchers also investigated the impact of POPs on male reproductive health in men from southern and northern Norway. The authors hypothesized that men residing closer to the Arctic Circle would accumulate more POPs, specifically 2,2'4, $4^{\prime}, 5,5^{\prime}$-hexachlorobiphenyl (CB-153) and p, p'-DDE. However, plasma levels of CB-153 did not differ significantly between men from the south and north, and $\mathrm{p}, \mathrm{p}^{\prime}$-DDE levels were higher in the southern population. CB-153 and sex hormone-binding globulin (SHBG) were positively correlated. There was no association between sperm motility and CB-153 or p, p'-DDE, but a link was observed between sperm concentration and CB-153 in the south [71]. A population from the Faroe Islands was analyzed for correlations between p, p'-DDE and PCBs and sperm disomy, as this population has a history of high organochlorine exposure. Men with elevated exposure to $\mathrm{p}, \mathrm{p}^{\prime}$-DDE and PCBs had higher rates of extra $\mathrm{X}$ chromosome and total sex-chromosome disomy. This study also included a birth cohort in which blood levels of p, p'-DDE and PCBs were measured in cord blood, at 14 years and in adulthood. Sex-chromosome disomy was associated with exposure to organochlorines at 14 years of age, which is the time for onset of puberty [72]. Secondary sex ratio (SSR) and exposure to POPs have also been studied in couples attending a fertility clinic, but there was no clear correlation between paternal exposure and SSR [73]. Levels of CB-153 and p, p'-DDE in serum were correlated with $C A G$ repeats characteristic for androgen receptors. In the group with less than 20 CAG repeats, CB-153 was significantly related to decreased sperm number, assessed as total count and concentration, while $\mathrm{p}, \mathrm{p}^{\prime}$-DDE was associated with sperm DNA fragmentation index (DFI) in the group with $\leq 21 \mathrm{CAG}$ repeats. These results indicated that CAG repeats in androgen receptors might modify the effect of POPs on semen quality [74]. A large cross-sectional study on exposure to CB-153 and p, p'-DDE was conducted on men from Greenland, anglers from Sweden, and men from Kharkov 
in Ukraine and from Warsaw, Poland. They showed that sperm motility was inversely correlated with CB-153 concentration in Greenland and in Swedish anglers, while sperm concentration and morphology were not associated with CB-153 and p, p'-DDE levels in serum [75]. The same cohort was tested for $X$ - and Y-chromosome-bearing sperm, and showed higher proportions of Y-chromosome sperm in Swedish and Greenlandic men, with higher serum levels of CB-153 compared to men from Warsaw and Kharkov. Logtransformed CB-153 and p, p'-DDE were also positively associated with Y-chromosome fractions in Swedish men. On the other hand, in a Polish cohort, CB-153 was negatively associated with the proportion of Y-chromosomes [76]. Since Inuits are highly exposed to POPs, their reproductive status and levels of CB-153 and p, p'-DDE were investigated. Inuits had low levels of DNA damage, tested by TUNEL assay, and their apoptosis markers were not associated with p, p'-DDE levels or CB-153 levels. These findings contrasted with a study on European males, in which exposure to CB-153 was associated with DNA integrity and levels of the anti-apoptotic protein Bcl-xL [77].

Urinary metabolites of non-persistent insecticides were also measured in men attending an infertility clinic in Poland. Lower sperm motility and higher DFI were associated with elevated concentrations of the chlorpyrifos metabolite 3,5,6-trichloro-2-pyridinol (TCPY). Furthermore, higher levels of morphologically abnormal sperm were associated with elevated levels of 1-naphtanol (1-N), a biomarker for the carbamate insecticide carbaryl [78]. A US case-control study measured non-persistent pesticide metabolites, which included the herbicides alachlor and atrazine as well as the insecticide diazinon, and men with higher serum levels of alachlor or diazinon were found to be more likely to have abnormal sperm parameters. These men came from agricultural regions of mid-Missouri $[79,80]$. 
Table 2. Epidemiologic studies estimating association between pesticide exposure and male infertility.

\begin{tabular}{|c|c|c|c|c|c|c|c|}
\hline Study & Site & Design & Exposure & $\begin{array}{l}\text { Duration of } \\
\text { Exposure }\end{array}$ & Sample & Outcome & Results \\
\hline Abell et al., 2000 [1] & Denmark & Cross-sectional & $\begin{array}{l}\text { Self- and greenhouse } \\
\text { owners reported } \\
\text { workplace pesticide } \\
\text { exposure }\end{array}$ & $\begin{array}{l}\text { Short- and } \\
\text { long-term }\end{array}$ & $\begin{array}{l}n=122 \text { healthy men } \\
\text { from } 30 \text { ornamental } \\
\text { flower greenhouses }\end{array}$ & $\begin{array}{l}\text { Semen analysis and } \\
\text { sex hormones }\end{array}$ & $\begin{array}{l}\text { Median sperm concentration } 40 \% \text { lower in men } \\
\text { with }>10 \text { years vs. men with }<5 \text { years' } \\
\text { experience. Age adjusted T/SHBG declined } 1.9 \% \\
(95 \% \text { CI } 0.4-3.4 \%) \text { per year of work. }\end{array}$ \\
\hline $\begin{array}{l}\text { Aguilar-Garduno et al., } \\
\text { 2012 [60] }\end{array}$ & Mexico & $\begin{array}{l}\text { Longitudinal } \\
\text { study }\end{array}$ & $\begin{array}{l}\text { Urine DAP metabolites } \\
\text { and serum } p, p^{\prime} \text {-DDE }\end{array}$ & Long-term & $\begin{array}{l}n=136 \text { healthy } \\
\text { industry workers }\end{array}$ & $\begin{array}{l}\text { Semen analysis, sex } \\
\text { hormones and } \\
\text { PON1 activity }\end{array}$ & $\begin{array}{l}\text { DEPT inversely assocaied with LH. Estradiol } \\
\text { marginally significant positive trend with DEP } \\
\text { and DEPT. }\end{array}$ \\
\hline Bae et al., 2018 [73] & United States & $\begin{array}{l}\text { Prospective } \\
\text { cohort study }\end{array}$ & $\begin{array}{l}\text { Serum OCPs (9), PBB } \\
\text { (1), PBDEs (10) and } \\
\text { PCBs (36) }\end{array}$ & Current & $\begin{array}{l}n=235 \text { men from } \\
\text { couples undergoing } \\
\text { fertility evaluation }\end{array}$ & Secondary sex ratio & $\begin{array}{l}\text { Maternal PCB-128 and paternal HCB associated } \\
\text { with female excess (RRs, } 0.75[95 \% \text { CI, } 0.60-0.94] \\
\text { and } 0.81 \text { [ } 95 \% \text { CI, } 0.68-0.97] \text {. Maternal mirex and } \\
\text { paternal PCB } 128 \text { and } p, p^{\prime}-\mathrm{DDE} \text { associated with a } \\
\text { male excess (RR range, } 1.10-1.22) \text {. Only maternal } \\
\text { mirex associated at } p<0.0009 \text {. }\end{array}$ \\
\hline Celik-Ozenci et al., 2012 [59] & Turkey & Cross-sectional & $\begin{array}{l}\text { Workplace abamectin } \\
\text { exposure }\end{array}$ & Long-term & $\begin{array}{c}n=20 \text { exposed and } \\
20 \text { non-exposed men }\end{array}$ & $\begin{array}{l}\text { Semen analysis, sperm } \\
\text { maturity and } \\
\text { sex hormones }\end{array}$ & $\begin{array}{l}\text { Exposed group associated with decreased } \\
\text { motility and increased sperm immaturity. }\end{array}$ \\
\hline $\begin{array}{l}\text { Cesaire Momo Tetsatsi et al., } \\
2020[50]\end{array}$ & Cameroon & $\begin{array}{l}\text { Descriptive } \\
\text { retrospective } \\
\text { study }\end{array}$ & Patient files & Historic & $n=379$ men & $\begin{array}{l}\text { Data on previous } \\
\text { semen analysis }\end{array}$ & $\begin{array}{c}\text { Farmers associated with the lowest } \\
\text { quality spermogram. }\end{array}$ \\
\hline Cremonese et al., 2017 [54] & Brazil & Cross-sectional & $\begin{array}{l}\text { Self-reported } \\
\text { application of pesticides }\end{array}$ & $\begin{array}{l}\text { Long-term, } \\
\text { maternal } \\
\text { during } \\
\text { pregnancy }\end{array}$ & $\begin{array}{c}n=99 \text { rural men and } \\
36 \text { urban men }\end{array}$ & $\begin{array}{l}\text { Semen analysis, sex } \\
\text { hormones and genital } \\
\text { measurements }\end{array}$ & $\begin{array}{l}\text { Rural men had poorer sperm morphology and } \\
\text { count and lower LH. Maternal farming during } \\
\text { pregnancy associated with larger AGD and TV. }\end{array}$ \\
\hline Dhooge et al., 2007 [57] & Belgium & Cross-sectional & $\begin{array}{l}\text { Reported consumption } \\
\text { of self-grown vegetables }\end{array}$ & Long-term & $n=51$ men & $\begin{array}{l}\text { Semen analysis and } \\
\text { sex hormones }\end{array}$ & $\begin{array}{l}\text { Locally produced vegetables associated with } \\
\text { lower free T, sperm concentration, morphology, } \\
\text { LH and FSH decline }(p=0.04, p=0.04, p=0.002 \text {, } \\
\qquad p=0.02, p=0.08) .\end{array}$ \\
\hline Dziewirska et al., 2019 [78] & Poland & Cross-sectional & Urinary $1 \mathrm{~N}$ and TCPY & Current & $\begin{array}{l}n=315 \text { men with } \\
\text { normal semen } \\
\text { concentration, under } \\
45 \text { years of age }\end{array}$ & $\begin{array}{l}\text { Semen analysis and } \\
\text { DNA fragmentation }\end{array}$ & $\begin{array}{l}\text { TCPY concentration associated with decreased } \\
\text { motility, positive association with DFI. } 1 \mathrm{~N} \\
\text { negatively associated with normal morphology } \\
\text { and positively with CASA parameters. }\end{array}$ \\
\hline
\end{tabular}


Table 2. Cont.

\begin{tabular}{|c|c|c|c|c|c|c|c|}
\hline Study & Site & Design & Exposure & $\begin{array}{l}\text { Duration of } \\
\text { Exposure }\end{array}$ & Sample & Outcome & Results \\
\hline Giwercman et al., 2007 [74] & Europe & Cross-sectional & $\begin{array}{l}\text { Serum cb-153 and } \\
\quad p, p^{\prime} \text {-DDE }\end{array}$ & Long-term & $\begin{array}{c}n=680 \text { men from } \\
\text { Greenland (188), } \\
\text { Warsaw (167), } \\
\text { Swedish fisherman } \\
(178), \text { Kharkiv (147) }\end{array}$ & $\begin{array}{l}\text { Semen analysis, sperm } \\
\text { DNA fragmentation, } \\
\text { CAG and GGN repeats } \\
\text { in leukocytes }\end{array}$ & $\begin{array}{l}\text { CB-153 group }(p=0.03) \text { and CAG repeat category } \\
(p=0.01) \text { associated with sperm concentration and } \\
\text { total count. } p, p^{\prime}-\mathrm{DDE} \text { associated with DFI }(p=0.01) \text {. } \\
\text { Above vs. below median CB-153 associated with } \\
\text { lower sperm concentration and total count for } \\
\text { CAG }<20 \text {. DFI associated with } p, p^{\prime} \text {-DDE for CAG } \leq 21\end{array}$ \\
\hline Haugen et al., 2011 [71] & Norway & Cross-sectional & $\begin{array}{l}\text { Serum CB-153 and } p \\
p^{\prime} \text {-DDE }\end{array}$ & Long-term & $\begin{array}{c}n=197 \text { men from } \\
\text { southern or northern } \\
\text { Norway }\end{array}$ & $\begin{array}{c}\text { Semen analysis and sex } \\
\text { hormones }\end{array}$ & $\begin{array}{l}\text { Levels of } p, p^{\prime} \text {-DDE, total and free T higher in south, } \\
\text { FSH lower. CB-153 and SHBG associated in total, } \\
\text { south and north cohorts }(\mathrm{B}=0.12, p<0.01 ; \mathrm{B}=0.13 \text {, } \\
\qquad p=0.01 ; \mathrm{B}=0.12, p<0.01)\end{array}$ \\
\hline Hauser et al., 2003 [70] & $\begin{array}{l}\text { United } \\
\text { States }\end{array}$ & Cross-sectional & $\begin{array}{c}\text { Serum PCBs and } p, \\
p^{\prime} \text {-DDE }\end{array}$ & Current & $\begin{array}{c}n=212 \text { men } \\
\text { undergoing fertility } \\
\text { evaluation }\end{array}$ & Semen analysis & $\begin{array}{c}\text { Dose-response relationship between PCB-138, sperm } \\
\text { motility }(\mathrm{OR}=1.00,1.68,2.35, p \text {-value }=0.03) \text { and } \\
\text { morphology }(\mathrm{OR}=1.00,1.36,2.53, p=0.04)\end{array}$ \\
\hline Hu et al., 2020 [61] & China & Cross-sectional & $\begin{array}{c}\text { Urinary pyrethroid } \\
\text { metabolites }\end{array}$ & Current & $\begin{array}{l}n=346 \text { men } \\
\text { undergoing fertility } \\
\text { evaluation }\end{array}$ & Semen analysis & $\begin{array}{c}\text { Negative association of 3PBA and morphology } \\
(B=-2.12,95 \% \mathrm{CI}-4.02 \text { to }-0.22), \text { TDCCA and log } \\
\text { transformed total count }(B=-0.09,95 \% \mathrm{CI}:-0.16 \text { to } \\
-0.01) ; 4 \text { thQ 3PBA associated with lower sperm } \\
\text { parameters and morphology (OR }=2.40,95 \% \mathrm{CI} \text { : } \\
1.26-4.54 ; \mathrm{OR}=3.08,95 \% \mathrm{CI}: 1.10-8.60) .\end{array}$ \\
\hline Imai et al., 2014 [64] & Japan & Cross-sectional & Urinary 3-PBA & Current & $\begin{array}{c}n=323 \text { male } \\
\text { university students }\end{array}$ & Semen analysis & No association between 3-PBA and semen quality \\
\hline Ji et al., 2011 [62] & China & Cross-sectional & $\begin{array}{l}\text { Urinary pyrethroid } \\
\text { metabolites }\end{array}$ & Current & $\begin{array}{l}n=240 \text { men } \\
\text { undergoing fertility } \\
\text { evaluation }\end{array}$ & $\begin{array}{l}\text { Semen analysis and } \\
\text { DNA fragmentation }\end{array}$ & $\begin{array}{c}\text { Inverse correlation between 3-PBA and sperm } \\
\text { concentration }(B=-0.27,95 \% \mathrm{CI}:-0.41 \text { to }-0.12, \\
p<0.001) \text {. Positive correlation between 3-PBA and } \\
\text { DFI }(B=0.27,95 \% \text { CI: } 0.15-0.39, p<0.001)\end{array}$ \\
\hline Lwin et al., 2018 [51] & Myanmar & Cross-sectional & $\begin{array}{c}\text { Self-reported } \\
\text { application of pesticides }\end{array}$ & Long-term & $n=400$ & $\begin{array}{l}\text { Semen analysis, sex } \\
\text { hormones and plasma } \\
\text { cholinesterase }\end{array}$ & $\begin{array}{c}\text { Differences in seminal parameters and sex hormones } \\
(p<0.05) \text { between growing and nongrowing period. } \\
\text { Cholinesterase levels significantly higher in growing } \\
\text { periods }(p<0.05)\end{array}$ \\
\hline Luderer et al., 2013 [81] & $\begin{array}{l}\text { United } \\
\text { States }\end{array}$ & $\begin{array}{c}\text { Nested } \\
\text { case-control }\end{array}$ & $\begin{array}{l}\text { Mothers of participants } \\
\text { reported heptachlor } \\
\text { epoxide exposure }\end{array}$ & $\begin{array}{l}\text { Maternal, } \\
\text { during } \\
\text { pregnancy and } \\
\text { lactation }\end{array}$ & $\begin{array}{c}n=216 \text { males and } \\
183 \text { females born in } \\
\text { Oahu, Hawaii during } \\
1981-1982\end{array}$ & $\begin{array}{l}\text { Semen analysis, sex } \\
\text { hormones and onset } \\
\text { of puberty }\end{array}$ & $\begin{array}{l}\text { No strong association, weak association in males } \\
\text { with higher FSH and LH concentrations, no } \\
\text { dose-response relationship. }\end{array}$ \\
\hline
\end{tabular}


Table 2. Cont

\begin{tabular}{|c|c|c|c|c|c|c|c|}
\hline Study & Site & Design & Exposure & $\begin{array}{l}\text { Duration of } \\
\text { Exposure }\end{array}$ & Sample & Outcome & Results \\
\hline Meeker et al., 2008 [67] & $\begin{array}{l}\text { United } \\
\text { States }\end{array}$ & Cross-sectional & $\begin{array}{l}\text { Urinary pyrethroid } \\
\text { metabolites }\end{array}$ & Current & $\begin{array}{c}n=207 \text { men } \\
\text { undergoing fertility } \\
\text { evaluation }\end{array}$ & $\begin{array}{l}\text { Semen analysis and } \\
\text { sperm DNA damage }\end{array}$ & $\begin{array}{c}\text { 4thQ 3PBA associated with concentration reduction } \\
\text { (95\%CI: }-37.1 \text { to +2.6). } 4 \text { thQ TDCCA associated with } \\
\text { motility decline }(95 \% \mathrm{CI}:-26.2 \text { to }-4.8) \text {. 3-PBA and } \\
\text { CDCCA associated with increased sperm } \\
\text { DNA damage. }\end{array}$ \\
\hline $\begin{array}{l}\text { Miranda-Contresas et al., } \\
2013 \text { [55] }\end{array}$ & Venezuela & Cross-sectional & $\begin{array}{l}\text { Self-reported workplace } \\
\text { pesticide exposure }\end{array}$ & Long-term & $\begin{array}{l}n=64 \text { male farm } \\
\text { workers and } \\
35 \text { healthy men, } \\
18-52 \text { years of age }\end{array}$ & $\begin{array}{l}\text { Sperm analysis, DNA } \\
\text { fragmentation, sex } \\
\text { hormone analysis and } \\
\text { cholinesterase activity }\end{array}$ & $\begin{array}{c}\text { DFI negatively correlated with BuChE, sperm } \\
\text { concentration, morphology and vitality in farm } \\
\text { workers. No association with levels of Tt, PRL, FT4 } \\
\text { and TSH. Tendency for increased LH and FSH in } \\
\text { exposed workers. }\end{array}$ \\
\hline Neghab et al., 2014 [53] & Iran & Cross-sectional & $\begin{array}{l}\text { Self-reported } \\
\text { application of pesticides }\end{array}$ & Long-term & $\begin{array}{l}n=268 \text { randomly } \\
\text { selected married } \\
\text { farm workers }\end{array}$ & Primary infertility & $\begin{array}{l}\text { Primary infertility higher among farm workers } \\
(p<0.05) \text {. Stillbirth and spontaneous abortion more } \\
\text { common in wives of farm workers. }\end{array}$ \\
\hline Pant et al., 2014 [69] & India & Case-control & $\begin{array}{l}\text { Seminal levels of } p \\
p^{\prime} \text {-DDE and lindane }\end{array}$ & Current & $\begin{array}{c}n=278 \text { men } \\
\text { undergoing fertility } \\
\text { evaluation } \\
\text { (21-40 years of age) }\end{array}$ & $\begin{array}{l}\text { Semen analysis, sperm } \\
\text { mitochondrial status, } \\
\text { ROS and SCSA }\end{array}$ & $\begin{array}{c}\text { Correlation between seminal lindane, } p, p^{\prime} \text {-DDE, } \\
\text { concentration }(\mathrm{r}=-0.53,-0.48) \text { and motility } \\
(\mathrm{r}=-0.51,-0.37) \text {. Positive association between } p \\
p^{\prime} \text {-DDE, lindane, ROS }(\mathrm{r}=0.61,0.53) \text {, lipid } \\
\text { peroxidation }(\mathrm{r}=0.58,0.51) \text { and MM dysfunction }\end{array}$ \\
\hline Radwan et al., 2014 [66] & Poland & Cross-sectional & $\begin{array}{l}\text { Urinary pyrethroid } \\
\text { metabolites }\end{array}$ & Current & $\begin{array}{c}n=334 \text { men } \\
\text { undergoing fertility } \\
\text { evaluation }\end{array}$ & $\begin{array}{l}\text { Semen analysis and } \\
\text { sex hormones }\end{array}$ & $\begin{array}{c}\text { Urinary pyrethroids associated with abnormal } \\
\text { morphology (CDCCA, TDCCA, sum of pyrethroids) } \\
\text { and decreased concentration, T level (TDCCA) and } \\
\text { CASA parameters (LIN to 3-PBA and DBCA; VSL to } \\
\text { VCL and DBCA). }\end{array}$ \\
\hline Stronati et al., 2006 [77] & Europe & Cross-sectional & $\underset{p^{\prime} \text {-DDE }}{\text { Serum } \mathrm{CB}-153 \text { and } p}$ & Long-term & $\begin{array}{c}n=798 \text { men from } \\
\text { Greenland (201), } \\
\text { Warsaw (198), } \\
\text { Swedish fisherman } \\
\text { (191), Kharkiv (208) }\end{array}$ & $\begin{array}{l}\text { Sperm DNA } \\
\text { fragmentation and } \\
\text { apoptosis }\end{array}$ & $\begin{array}{l}\text { CB-153 associated with altered sperm DNA integrity } \\
\text { and Bcl-xL levels-No association for } p, p^{\prime} \text {-DDE. }\end{array}$ \\
\hline
\end{tabular}


Table 2. Cont.

\begin{tabular}{|c|c|c|c|c|c|c|c|}
\hline Study & Site & Design & Exposure & $\begin{array}{l}\text { Duration of } \\
\text { Exposure }\end{array}$ & Sample & Outcome & Results \\
\hline Swan et al., 2003 [80] & $\begin{array}{l}\text { United } \\
\text { States }\end{array}$ & Case-control & $\begin{array}{l}\text { Serum pesticide and } \\
\text { herbicide metabolites }\end{array}$ & Long-term & $\begin{array}{c}n=50 \text { cases and } \\
36 \text { controls }\end{array}$ & Semen analysis & $\begin{array}{c}\text { Cases had higher levels of alachlor or IMPY } \\
\text { (ORs }=30.0 \text { and 16.7) and atrazine levels higher than } \\
\text { LOD }(\mathrm{OR}=11.3) .2,4-\mathrm{D} \text { and metolachlor associated } \\
\text { with poor semen quality. Acetochlor levels lower in } \\
\text { cases vs. controls }(p=0.04) .\end{array}$ \\
\hline Swan et al., 2006 [79] & $\begin{array}{l}\text { United } \\
\text { States }\end{array}$ & $\begin{array}{c}\text { Nested } \\
\text { case-control }\end{array}$ & $\begin{array}{l}\text { Serum non-persistent } \\
\text { pesticide (8) metabolites }\end{array}$ & Current & $\begin{array}{c}n=25 \text { cases and } \\
25 \text { controls }\end{array}$ & Semen analysis & $\begin{array}{l}\text { High levels of alachlor or diazinon }(\mathrm{OR}=30.0,16.7) \\
\text { and men with atrazine }(\mathrm{OR}=11.3) \text { over LOD } \\
\text { significantly more among cases. }\end{array}$ \\
\hline Tiido et al., 2006 [76] & Europe & Cross-sectional & $\begin{array}{l}\text { Serum PCB-153 and } p, \\
p^{\prime} \text {-DDE }\end{array}$ & Long-term & $\begin{array}{c}n=547 \text { men from } \\
\text { Greenland (157), } \\
\text { Warsaw (121), } \\
\text { Swedish fisherman } \\
\text { (149), Kharkov (120) }\end{array}$ & $\mathrm{Y}: \mathrm{X}$ ratio & $\begin{array}{c}\text { Y-sperm associated with higher PCB-153 in } \\
\text { Greenlandic and Swedish vs. Warsaw and Kharkov } \\
\text { men. Log-transformed PCB-153 }(p=0.04) \text { and } p \\
p^{\prime} \text {-DDE }(p<0.001) \text { associated with Y-fraction. } \\
\text { Negatively associated PCB-153 and Y-chromosome in } \\
\text { Polish cohort }(p=0.008)\end{array}$ \\
\hline Toft et al., 2006 [75] & Europe & Cross-sectional & $\begin{array}{l}\text { Serum CB-153 and } p \\
p^{\prime} \text {-DDE }\end{array}$ & Long-term & $\begin{array}{c}n=763 \text { men from } \\
\text { Greenland (194), } \\
\text { Warsaw (189), } \\
\text { Swedish fisherman } \\
\text { (185), Kharkov (195) }\end{array}$ & Semen analysis & $\begin{array}{c}\text { In all regions, sperm motility associated with } \mathrm{CB}-153 \\
\text { blood concentration }(B=-3.6 \% \text { per log unit } \mathrm{CB}-153 \\
(\mathrm{ng} / \mathrm{g} \text { lipid); } 95 \% \mathrm{CI}=-5.6 \text { to }-1.7) \cdot p, p^{\prime} \text {-DDE } \\
\text { negatively associated with motility in } \\
\text { Greenlandic population. }\end{array}$ \\
\hline Toshima et al., 2012 [65] & Japan & Pilot study & $\begin{array}{l}\text { Urinary metabolites of } \\
5 \text { phthalate diesters, } \\
\text { pyrethroids, soy } \\
\text { isoflavones and } \\
\text { cadmium }\end{array}$ & Current & $\begin{array}{l}n=42 \text { men from } \\
\text { couples undergoing } \\
\text { fertility evaluation }\end{array}$ & Semen analysis & $\begin{array}{c}\text { Weak positive correlation between concentration and } \\
\text { cadmium ( } \mathrm{r}=-0.316, \\
p=0.044) \text {. Negative correlation between } \\
\text { concentration and daidzein }(\mathrm{r}=-0.292, \\
p=0.064) . \text { Equol correlated to motility }(48.2 \pm 21.0 \% \\
\text { in equol non-detectable group vs. } 32.5 \pm 16.8 \% \text { in } \\
\text { equol detectable, } p=0.013) .\end{array}$ \\
\hline Young et al., 2013 [68] & $\begin{array}{l}\text { United } \\
\text { States }\end{array}$ & Cross-sectional & $\begin{array}{l}\text { Urinary pyrethroids: } \\
\text { 3-PBA, CDCCA and } \\
\text { TDCCA }\end{array}$ & Current & $\begin{array}{l}n=75 \text { men } \\
\text { undergoing fertility } \\
\text { evaluation }\end{array}$ & $\begin{array}{c}\mathrm{X}, \mathrm{Y} \text { and } 18 \\
\text { chromosomes disomy }\end{array}$ & $\begin{array}{c}\text { Sex chromosome disomies increased } 7-30 \% \text { in men } \\
\text { above LOD vs. below LOD. YY18 disomy } 1.28 \text { times } \\
\text { higher in 3-PBA group above LOD ( } 95 \% \text { CI: } 1.15 ; 1.42) \text {. } \\
\text { Reduced rate for XY18 and total disomy for 3-PBA } \\
\text { (IRR = 0.82, 95\% CI: } 0.77 ; 0.87 ; \text { IRR }=0.93 ; 95 \% \text { CI: } \\
0.87-0,97) \text {. No association for XX18 and } 1818 .\end{array}$ \\
\hline Yoshinaga et al., 2014 [63] & Japan & Cross-sectional & Urinary 3-PBA & Current & $\begin{array}{l}n=322 \text { male } \\
\text { university students }\end{array}$ & Sex hormones & No association between 3-PBA and hormone levels. \\
\hline
\end{tabular}


Table 2. Cont.

\begin{tabular}{|c|c|c|c|c|c|c|c|}
\hline Study & Site & Design & Exposure & $\begin{array}{l}\text { Duration of } \\
\text { Exposure }\end{array}$ & Sample & Outcome & Results \\
\hline Yucra et al., 2006 [56] & Peru & Cross-sectional & $\begin{array}{l}\text { Self-reported workplace } \\
\text { pesticide exposure }\end{array}$ & Long-term & $\begin{array}{c}n=31 \text { pesticide } \\
\text { applicators and } 80 \\
\text { non-exposed }\end{array}$ & $\begin{array}{c}\text { Semen analysis and sex } \\
\text { hormones }\end{array}$ & $\begin{array}{c}\text { Volume }(p=0.02), \text { motility grade } \mathrm{A}(p=0.003) \text {, grade } \\
\mathrm{A}+\mathrm{B}(p=0.002), \text { normal morphology } \\
(p=0.000) \text { and zinc concentration }(p=0.02) \text { lower, } \\
\text { while } \mathrm{pH}(p=0.003), \text { liquefaction }(p=0.000), \\
\text { immature sperm }(p=0.01) \text { and leukocytes }(p=0.000) \\
\text { higher in exposed men. T and LH levels lower } \\
(p=0.001 \text { and } p=0.02), \mathrm{T} / \mathrm{LH} \text { significantly higher } \\
(p=0.001) \text { in exposed men. }\end{array}$ \\
\hline
\end{tabular}

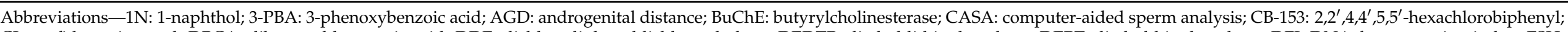

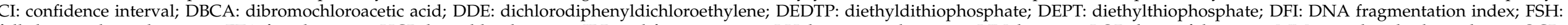

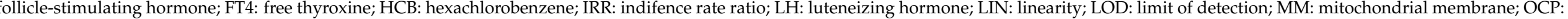

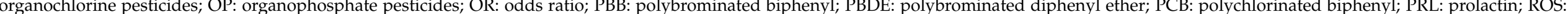

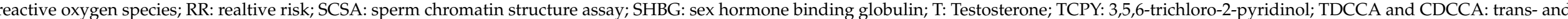
cis-3-(2,2-Dichlorovinyl)-2,2-dimethylcy clopropane carboxylic acid; TSH: thyroid stimulatinf hormone; TV: testis volume; VCL: curvilinear velocity. 


\subsection{Transplacental Exposure Impact on Fertility}

Transplacental exposure to pesticides is a very complex biological process whose final toxic or/and endocrine disrupting activity depends on the physicochemical properties of the substance or pesticide mixtures. Pesticides and their metabolites may interact synergistically or antagonistically. Using a human placental perfusion model for studying the pyrethroid cypermethrin and triazole fungicides propiconazole and bitertanol, it was shown that the placenta produces metabolites, thus exposing the mother and fetus to both the parent compounds and their metabolites [82]. The transplacental process is significantly affected by the lipid fraction, as lipophilic compounds can move across the placenta from maternal to fetal circulation. Accordingly, it is important to apply the lipid-adjusted ratio of concentrations in fetal and maternal circulation in risk assessments, as umbilical cord blood contains lower levels of lipids than maternal blood. The relationship of maternal and umbilical cord serum (or placenta) suggests that prenatal exposure to POPs may be estimated based on maternal serum pesticide concentrations $[83,84]$. The transplacental transfer of OCPs is a combination of simple diffusion and active transport [85]. Transplacental transfer depends on the physicochemical properties of pesticides such as polarity, molecular weight, lipophilicity and degree of chlorination or bromination, and may explain differences in maternal serum and cord blood pesticide levels [86]. The concentrations of organochlorine pesticides tend to be higher in mothers than in newborns and placental samples, except in the case of 4,4'-DDT, as fetal metabolizing and elimination mechanisms are less efficient than the mother's [84]. Fetuses also have lower levels of detoxifying enzymes (e.g., paraoxonase or chlorpyrifos-oxonase) that deactivate organophosphates than adults [87], and are more susceptible to these exposures.

In a long-term Danish follow-up study of girls whose mothers were exposed very early in pregnancy to pesticides through their work as greenhouse workers, the mean onset of pubertal breast development was significantly earlier (8.9 years) in prenatally exposed girls, compared to daughters of unexposed mothers (10.4 years) and the Danish reference population. Transplacentally exposed girls had significantly higher serum androstenedione levels and lower AMH compared with unexposed participants, while levels of testosterone and estradiol did not differ between the groups [88]. Testicular volume and penile length were reduced in prenatally exposed sons of mothers occupationally exposed to pesticides. The effects were dose-related, although pituitary and testicular hormone serum concentrations did not differ between exposed and unexposed sons. Of 59 prenatally exposed boys, 8 had genital malformations, while there were no malformations among the unexposed boys [89]. However, in a similar study, the serum concentrations of sex hormone-binding globulin (SHBG) and the luteinizing hormone:testosterone ratio were increased compared to boys from unexposed mothers [90]. Occupational exposure to pesticides in both parents was a statistically significant risk for cryptorchidism, hypospadias and micropenis in newborns [91].

Organochlorine pesticide levels in the maternal blood, cord blood and placenta of mothers delivering small for gestational age babies were higher compared to mothers delivering appropriate for gestational age babies. In utero exposure to hexachlorocyclohexane $(\mathrm{HCH})$ and other OCPs had a significant adverse effect on birth size. Following The Stockholm Convention (2001), HCH by itself is no longer produced or available on the market, but it is still present in the environment and in human populations [92,93]. The mother's consumption of meat and milk significantly contributes to the levels of beta $\mathrm{HCH}$ in umbilical cord blood [94]. During fetal development, the female phenotype is the default condition, and male development requires testicular testosterone and AMH [95]. Thus, anti-androgenic OCP activities might be more severe in boys than estrogenic activities are in girls.

Although DDT has been banned in most parts of the world, it is still present in the environment and human exposure significantly varies between continents and countries [96]. In utero exposure to DDT is associated with reduced head circumference, crown-heel 
length, birth weight and birth length, which are independent of gestational age and/or preterm births. However, it has been suggested that this effect is detrimental [97].

Exposure to $\mathrm{p}, \mathrm{p}^{\prime}$-DDE in utero is associated with shortened anal genital index among boys but not among girls, which may be caused by androgen deficiency after the reduction of transcriptional activity due to AR being blocked by $\mathrm{p}, \mathrm{p}^{\prime}$-DDE in utero [98]. A significantly increased excess risk of urogenital malformations among the sons of exposed mothers was found in the presence of placental $o, p^{\prime}$-DDT, $p, p^{\prime}$-DDT, endosulfan- $\alpha$, lindane and Mirex [99]. Maternal prenatal levels of $p, p^{\prime}$-DDT were significantly inversely associated with testosterone levels, adjusted for Tanner stage [100], while there was no statistically significant association for $\mathrm{p}, \mathrm{p}^{\prime}$-DDE [100,101].

In the daughters of mothers exposed to pesticides, the probability of a pregnancy fell by $32 \%$ per 10 microg/L p,p'-DDT in maternal serum, and increased $16 \%$ per 10 microg/L p,p'-DDE [102]. Both compounds are endocrine disruptors, which impact several mechanisms, such as p,p DEE induces aromatase and DDT suppresses androgen receptor-mediated activity [103,104].

Diuron (3-(3,4-di-chlorophenyl)-1,1-dimethylurea) is a herbicide banned in many parts of Europe, but due to its high stability and persistence, it is a contaminant of water in different areas of Europe and the US. Its toxic metabolite, 3-(3,4-dichlorophenyl)-1-methyl urea, crosses the human placenta and may result in fetotoxicity [105].

A disturbance of sex hormones in newborns was reported in association with maternal pesticide exposure in several studies. Significant reductions in estradiol, testosterone and the testosterone/E2 ratio were shown to be associated with dialkylphosphate, a metabolite that may disturb the development of the neuroendocrine axis, in newborns [106]. Similarly, sex hormone disturbances were detected for chlorpyrifos, which irreversibly inhibit CYP3A4 and the formation of 3-hydroxycarbofuran in human liver microsomes, causing te activation of testosterone metabolism and reductions in testosterone levels [107]. A gender-specific disturbance of sex hormones was reported for chlordanes, cis-HCB, heptachlor epoxide, Mirex and toxaphenes. Their levels in maternal blood were inversely associated with testosterone, SHBG and androstenedione-dehydroepiandrosterone in boys, while in girls, $\mathrm{p}, \mathrm{p}^{\prime}$-DDT was inversely associated with the level of androstenedionedehydroepiandrosterone $[108,109]$.

An association between isolated hypospadias and the presence of the phenylurea herbicide isoproturon and the phenoxyherbicide 2-methyl-4-chlorophenoxyacetic acid in meconium has been detected [110].

It is important to stress that transplacental exposure to pesticides may disturb not only sex differentiation of the fetus, but also its sex-specific brain development. After crossing the placental barrier, pesticides pass through the blood-brain barrier of a fetus [111], which may impact behavior later in life [112], and as hypothesized for endocrine disruption, may affect gender identity in human populations [113].

\subsection{Genetic Susceptibility to Pesticide Exposure}

The majority of studies on interaction between genetic polymorphisms and exposure to pesticides have focused on cancer or neurodegenerative diseases, most often in case-control designs [114]. However, some studies of human paraoxonase 1 (PON1) polymorphisms and pesticide exposure have addressed other health effects, including effects on reproductive outcomes.

PON1 is a high-density lipoprotein (HDL)-associated esterase that hydrolyses a wide range of substrates, including some organophosphate insecticides. It also has antioxidant functions and protects lipoproteins from oxidative modifications [115]. PON1 is known to detoxify organophosphate insecticides by hydrolyzing the oxon-form of the parent compounds, and for most organophosphates the catalytic efficiency is higher among Rcarriers than QQ-homozygotes [116]. Therefor QQ-homozygotes are more susceptible to acute toxic effects after high exposure to most organophosphates. However, for diazoxon (the active oxon-metabolite of diazinon), R-carriers have a higher catalytic rate, explaining their higher susceptibility towards high diazinone exposure among sheep dippers carrying 
the R-allele [117]. At lower exposure levels, the capacity to detoxify organophosphates is considered to be independent of the PON1 Q192 genotype [118]. Thus, the higher susceptibility among R192-carriers reported in some of the studies above seems unrelated to the hydrolysis efficiency of the enzyme. The suggested mechanisms include lower anti-oxidative and anti-inflammatory efficiencies linked to the R-allele [115] causing Rcarriers to be more vulnerable to adverse effects on, e.g., ovarian function and semen quality mediated by oxidative stress after pesticide exposure. A differential methylation profile in neuroendocrine signaling pathways was observed in DNA isolated from blood samples from children with the R-allele after prenatal pesticide exposure compared to exposed children with the QQ-genotype or unexposed children [119]. Whether similar PON1-related changes in DNA-methylation are induced in adults after pesticide exposure has, to our knowledge, not yet been investigated.

Several polymorphisms in PON1 have been identified $[119,120]$. A common polymorphism in the coding sequence, a glutamine $(\mathrm{Q})$ /arginine $(\mathrm{R})$ substitute at position 192, affects both the catalytic capacity to detoxify organophosphates and the antioxidant function $[115,121]$. In a study from Mexico, women who had the RR genotype and were exposed to pesticides from floricultural work had a higher risk of having a baby with low birth weight than women with the QQ or QR genotype [122]. In another study, exposure to the organophosphate chlorpyrifos during pregnancy was associated with reduced head circumference in children at birth if the mothers had a low PON1 concentration, but no interaction was seen between exposure and maternal or child PON1 genotype on head circumference, birth weight or birth length [123]. However, within the same birth cohort, negative associations between maternal urinary concentrations of organophosphate metabolites and cognitive development were seen at 12 months of age, if the mothers had the QR/RR genotype, although children of mothers with the QQ-genotype appeared to be more affected in later childhood [124]. In another study, low infant, but not maternal, PON1 enzyme activity was associated with shorter gestation and smaller head circumference at birth independently of maternal organophosphate exposure [125]. However, for infants with low PON1 activity and PON1 -108TT and PON1 192QQ genotypes, prenatal organophosphate exposure was associated with shorter gestational agen. This finding might be related to lower expression levels of PON1 in fetuses and neonates, implying higher susceptibility to pesticides [126,127]. In a genetic study of Caucasian, Caribbean Hispanic, and African American neonates and their mothers, three PON1 promoter and two coding polymorphisms were investigated and for all genotypes the activity levels of the neonates were significantly lower than those of the mothers [128]. Another study on Latina mothers and their newborns showed that, the mean PON1 activity of the infants was fourfold lower than among the mothers [127]. In a Danish study among children of female greenhouse workers, prenatally pesticide-exposed children carrying the PON1 192R-allele had greater abdominal circumference, body fat content, body mass index (BMI) Z scores, blood pressure and serum concentrations of leptin and insulin growth factor-I at school age than unexposed children. The effects were associated with maternal pesticide exposure level during the first two months of pregnancy. For Q192 homozygote children, none of the variables were affected by prenatal pesticide exposure [129]. Furthermore, serum concentrations of leptin, glucagon and plasminogen activator inhibitor type-1 were enhanced in prenatally exposed children with the R-allele, also after adjusting for BMI [130]. The findings on body fat composition were still evident at adolescence (11-16 years) where dual $X$-ray absorptiometry (DXA), showed that android fat $\%$, gynoid fat $\%$ and total fat $\%$ were positively associated with prenatal pesticide exposure in R-carriers. When maternal PON1 genotype was also included, it was found that the associations were further strengthened if the mother also had an R-allele. In general, the associations were stronger in girls than in boys [131]. Thus, the potential impact of pesticide exposure during pregnancy might be modified by the genotype of both mother and fetus.

Regarding effects on male reproduction, a Chinese study on pesticide factory workers found that and exposed R192 homo/heterozygotes, but not Q192 homozygotes, had 
significantly lower sperm counts and fewer morphologically normal sperm compared to unexposed textile-factory workers. The results should be interpreted with caution because of a small sample size but the findings suggest that PON1 genotype may modify the effect of organophosphate exposure on male fertility [132] which was also supported by another study among Mexican farmers [133]. Among farmers exposed to sheep dip, using the organophosphate pesticide diazinon as its active ingredient, self-reported ill individuals were more likely to be carriers of the R192 allele compared with those without symptoms [116,134]. A similar association was observed in a study of pesticide-exposed South African farmers $[135,136]$.

\section{Discussion}

Our results show that multiple epidemiologic studies have reported statistically significant associations between reproductive disturbances and exposure to pesticides. However, most studies to date have focused on a single or limited set of pesticides, and there are few data available to assess the potential reproductive impacts of complex mixtures of the current, banned and new pesticides encountered by many populations, as well as potential interactions with other classes of endocrine disruptors.

While few relevant epidemiologic studies were captured by our search algorithm, the results were generally inconsistent, and as such inconclusive with respect to the associations of pesticide exposure with TTP and infertility. Even in large studies, the OCP results were inconsistent. Still, most studies used a retrospective assessment of TTP, which may introduce outcome misclassification, particularly for longer TTP [137], and enrolled women with ongoing pregnancies, excluding women with losses and without conception, who are possibly the most susceptible groups, which may bias the study results to null [138]. For non-persistent organophosphate, pyrethroid, and other pesticides, urinary metabolites offer a "snapshot" in time of recent exposure, and may thus misclassify exposure at critical biologic windows for reproductive health effects. In contrast, persistent OCPs and metabolites reflect long-term exposure, although physiologic changes may cause the misclassification of gestational exposure estimates in some women or introduce reverse causation [139], and non-fasting blood specimens may further confuse levels of lipophilic OCPs. Paternal exposures are also likely to play an important role in female fertility, and should be incorporated.

Genetic polymorphisms might play an important role in susceptibility to the adverse effects of pesticide exposure. For instance, PON1 levels differ significantly between individuals and between children and adults, a property that is highly relevant in the context of susceptibility to pesticides. Furthermore, PON1 polymorphisms are also differently distributed between ethnic groups. Among Caucasians, a PON1 192R-allele frequency of approximately $25 \%$ has been reported, but in other populations the R-allele frequency was considerably higher (40-70\%), particularly among South American and African populations, as well as being very high in Asian populations [140-142]. Thus, susceptibility to the adverse health effects of organophosphate insecticides is likely to be considerably different between different populations. Likewise, polymorphisms in other genes coding for pesticide-metabolizing enzymes (e.g., different cytochrome P450 (CYPs)) are differently distributed among populations and, although this is less studied, probably also affect susceptibility to the adverse reproductive health effects of pesticide exposure. Thus, genetic differences in vulnerability should be introduced into legislation.

Not only physiological, but also behavioral disturbances caused by the impact of pesticides on brain development may play a significant role for reduced fertility [143].

The potential of publication bias is recognized as errors in search strategies can impact the quality and validity of systematic reviews [144]. Our search strategy was carefully considered to help ensure the adequate coverage of the literature, and that no key articles were overlooked. The review was therefore reliant on the methodology employed, but also the published literature that is available. Our review focused on articles published in the English language. Given that others have cited that over 
roughly $80 \%$ of all the journals indexed in Scopus are published in English (van Weijen, 2012; https: / / www.researchtrends.com/issue-31-november-2012/the-language-of-futurescientific-communication / accessed on 1 June 2021) [145], and with more than $90 \%$ of the indexed scientific articles in the natural sciences being published in this language [146], it is considered that our review provides good coverage of the relevant publications. In our review, as part of the inclusion criteria, we focused on identifying studies where there had been self-reported occupational exposure and/or measured levels of metabolites in blood or urine. Both direct (e.g., biomonitoring) and indirect (e.g., self-reported exposures) exposure assessment methods (EAMs) are intrinsically associated with degrees of exposure misclassification, which might lead to conflicting study results [147]. The Improving Exposure Assessment Methodologies for Epidemiological Studies on Pesticides (IMPRESS) project aims to improve the understanding of the performance of pesticide EAMs used in previous epidemiological investigations [148], and it is considered that the future outputs of this will prove valuable when interpreting such studies.

\section{Conclusions}

In conclusion, our results show that the most frequently investigated pesticides with reported associations with human fertility are OCPs and their mixtures. Additionally, the urinary metabolites of pyrethroids were also investigated, which were often applied together with OCPs.

At present, fertility evaluations are not routinely incorporated into occupational health surveillance programs. However, our review of the literature suggests that this is crucial. Despite the fact that collecting data on fertility may cause discomfort in workers, or simply a refusal to respond, the introduction of biomarkers such as sex hormone levels could show the trend of exposure and the expected biological effect.

Future studies should also incorporate pesticide exposure in both partners, as available studies very rarely give holistic insights into family-level exposure.

Author Contributions: A.F. created the concept of the paper. A.F. took part in the selection of references, the writing, the editing and the final reading of the manuscript. T.M. took part in the selection of references, the writing, the editing and the final reading of the manuscript. R.C.D. took part in the selection of references, the writing, the editing and the final reading of the manuscript. M.S.B. took part in the selection of references, the writing, the editing and the final reading of the manuscript. J.E.V. took part in the selection of references, the writing, the editing and the final reading of the manuscript. H.R.A. took part in the selection of references, the writing, the editing and the final reading of the manuscript. K.S.G. took part in the selection of references, the writing, the editing and the final reading of the manuscript. K.G. took part in the selection of references, the writing, the editing and the final reading of the manuscript. All authors have read and agreed to the published version of the manuscript.

Funding: This paper received funding from the European Union Horizon 2020 research and innovation program under grant agreement No 733032 and the European Regional Development Fund, Operational Programme Competitiveness and Cohesion, under grant agreement No. KK.01.1.1.01.0008, Operational Programme Competitiveness and Cohesion, under grant agreement No. KK.01.1.1.01.0008, Regenerative and Reproductive Medicine - Exploring New Platforms and Potentials.

Institutional Review Board Statement: Not applicable.

Informed Consent Statement: Not applicable.

Conflicts of Interest: Authors declare no conflict of interest. 


\section{References}

1. Abell, A.; Ernst, E.; Bonde, J.P. Semen quality and sexual hormones in greenhouse workers. Scand. J. Work. Environ. Health 2000, 26, 492-500. [CrossRef] [PubMed]

2. Food and Agriculture Organization of the United Nations (FAO). Prevention and Disposal of Obsolete Pesticides. Available online: http:/ / www.fao.org/agriculture/crops/obsolete-pesticides/why-problem/pesticide-bans/en/ (accessed on 15 March 2021).

3. Pesticide Action Network International (PAN). PAN International Consolidated List of Banned Pesticides. Available online: http:/ / pan-international.org/pan-international-consolidated-list-of-banned-pesticides/ (accessed on 19 March 2021).

4. Donley, N. The USA lags behind other agricultural nations in banning harmful pesticides. Environ. Health 2019, 18, 1-12. [CrossRef] [PubMed]

5. UTZ. List of Banned Pesticides and Pesticides Watchlist. Version. Available online: https://utz.org/wp-content/uploads/2015/1 2/EN_UTZ_List-of-Banned-PesticidesWatchlist_v1.0_2015.pdf (accessed on 23 March 2021).

6. Di Renzo, G.C.; Conry, J.A.; Blake, J.; DeFrancesco, M.S.; DeNicola, N.; Martin, J.N., Jr.; McCue, K.A.; Richmond, D.; Shah, A.; Sutton, P.; et al. International Federation of Gynecology and Obstetrics opinion on reproductive health impacts of exposure to toxic environmental chemicals. Int. J. Gynecol. Obstet. 2015, 131, 219-225. [CrossRef] [PubMed]

7. American College of Obstetricians and Gynecologists; American Society for Reproductive Medicine. Exposure to toxic environmental agents. Obstet. Gynecol. 2013, 122, 931-935. [CrossRef] [PubMed]

8. Gore, A.C.; Chappell, V.A.; Fenton, S.E.; Flaws, J.; Nadal, A.; Prins, G.S.; Toppari, J.; Zoeller, R.T. EDC-2: The Endocrine Society's Second Scientific Statement on Endocrine-Disrupting Chemicals. Endocr. Rev. 2015, 36, E1-E150. [CrossRef]

9. La Merrill, M.A.; Vandenberg, L.N.; Smith, M.T.; Goodson, W.; Browne, P.; Patisaul, H.B.; Guyton, K.Z.; Kortenkamp, A.; Cogliano, V.J.; Woodruff, T.J.; et al. Consensus on the key characteristics of endocrine-disrupting chemicals as a basis for hazard identification. Nat. Rev. Endocrinol. 2020, 16, 45-57. [CrossRef] [PubMed]

10. Agarwal, A.; Aponte-Mellado, A.; Premkumar, B.J.; Shaman, A.; Gupta, S. The effects of oxidative stress on female reproduction: A review. Reprod. Biol. Endocrinol. 2012, 10, 49. [CrossRef]

11. Al-Gubory, K.H. Environmental pollutants and lifestyle factors induce oxidative stress and poor prenatal development. Reprod. Biomed. Online 2014, 29, 17-31. [CrossRef]

12. Giudice, L.C. Environmental toxicants: Hidden players on the reproductive stage. Fertil. Steril. 2016, 106, 791-794. [CrossRef] [PubMed]

13. Lee, D.-H.; Jacobs, D.R. Firm human evidence on harms of endocrine-disrupting chemicals was unlikely to be obtainable for methodological reasons. J. Clin. Epidemiol. 2019, 107, 107-115. [CrossRef]

14. Porta, M.; Vandenberg, L.N. There are good clinical, scientific, and social reasons to strengthen links between biomedical and environmental research. J. Clin. Epidemiol. 2019, 111, 124-126. [CrossRef] [PubMed]

15. Autrup, H.; Barile, F.A.; Berry, S.C.; Blaauboer, B.J.; Boobis, A.; Bolt, H.; Borgert, C.J.; Dekant, W.; Dietrich, D.; Domingo, J.L.; et al. Human exposure to synthetic endocrine disrupting chemicals (S-EDCs) is generally negligible as compared to natural compounds with higher or comparable endocrine activity: How to evaluate the risk of the S-EDCs? Arch. Toxicol. 2020, 94, $2549-2557$. [CrossRef] [PubMed]

16. Levine, H.; Jørgensen, N.; Martino-Andrade, A.; Mendiola, J.; Weksler-Derri, D.; Mindlis, I.; Pinotti, R.; Swan, S.H. Temporal trends in sperm count: A systematic review and meta-regression analysis. Hum. Reprod. Update 2017, 23, 646-659. [CrossRef] [PubMed]

17. Skakkebaek, N.E.; Meyts, E.R.-D.; Louis, G.M.B.; Toppari, J.; Andersson, A.-M.; Eisenberg, M.L.; Jensen, T.K.; Jørgensen, N.; Swan, S.H.; Sapra, K.J.; et al. Male Reproductive Disorders and Fertility Trends: Influences of Environment and Genetic Susceptibility. Physiol. Rev. 2016, 96, 55-97. [CrossRef] [PubMed]

18. Petraglia, F.; Serour, G.I.; Chapron, C. The changing prevalence of infertility. Int. J. Gynecol. Obstet. 2013, 123, S4-S8. [CrossRef]

19. Mascarenhas, M.N.; Flaxman, S.R.; Boerma, T.; Vanderpoel, S.; Stevens, G.A. National, Regional, and Global Trends in Infertility Prevalence Since 1990: A Systematic Analysis of 277 Health Surveys. PLoS Med. 2012, 9, e1001356. [CrossRef]

20. Zaccai, J.H. How to assess epidemiological studies. Postgrad. Med. J. 2004, 80, 140-147. [CrossRef]

21. Baird, D.D.; Wilcox, A.; Weinberg, C.R. Use of time to pregnancy to study environmental exposures. Am. J. Epidemiol. 1986, 124, 470-480. [CrossRef]

22. Gurunath, S.; Pandian, Z.; Anderson, R.A.; Bhattacharya, S. Defining infertility-A systematic review of prevalence studies. Hum. Reprod. Update 2011, 17, 575-588. [CrossRef] [PubMed]

23. Practice Committee of the American Society for Reproductive Medicine. Definitions of infertility and recurrent pregnancy loss. Fertil. Steril. 2008, 89, 1603. [CrossRef] [PubMed]

24. Björvang, R.D.; Gennings, C.; Lin, P.-I.; Hussein, G.; Kiviranta, H.; Rantakokko, P.; Ruokojärvi, P.; Lindh, C.H.; Damdimopoulou, P.; Bornehag, C.-G. Persistent organic pollutants, pre-pregnancy use of combined oral contraceptives, age, and time-to-pregnancy in the SELMA cohort. Environ. Health 2020, 19, 1-14. [CrossRef]

25. Carrico, C.; Gennings, C.; Wheeler, D.C.; Factor-Litvak, P. Characterization of Weighted Quantile Sum Regression for Highly Correlated Data in a Risk Analysis Setting. J. Agric. Biol. Environ. Stat. 2015, 20, 100-120. [CrossRef] [PubMed]

26. Hu, Y.; Ji, L.; Zhang, Y.; Shi, R.; Han, W.; Tse, L.A.; Pan, R.; Wang, Y.; Ding, G.; Xu, J.; et al. Organophosphate and Pyrethroid Pesticide Exposures Measured before Conception and Associations with Time to Pregnancy in Chinese Couples Enrolled in the Shanghai Birth Cohort. Environ. Health Perspect. 2018, 126, 077001. [CrossRef] 
27. Sanin, L.-H.; Carrasquilla, G.; Solomon, K.R.; Cole, D.C.; Marshall, E.J.P. Regional Differences in Time to Pregnancy Among Fertile Women from Five Colombian Regions with Different use of Glyphosate. J. Toxicol. Environ. Health Part. A 2009, 72, 949-960. [CrossRef] [PubMed]

28. Olsen, J.; Bonde, J.; Hjøllund, N.; Basso, O.; Ernst, E. Using infertile patients in epidemiologic studies on subfecundity and embryonal loss. Hum. Reprod. Update 2005, 11, 607-611. [CrossRef]

29. Cabry, R.; Merviel, P.; Madkour, A.; Lefranc, E.; Scheffler, F.; Desailloud, R.; Bach, V.; Benkhalifa, M. The impact of endocrine disruptor chemicals on oocyte/embryo and clinical outcomes in IVF. Endocr. Connect. 2020, 9, R134-R142. [CrossRef] [PubMed]

30. Mahalingaiah, S.; Missmer, S.A.; Maity, A.; Williams, P.L.; Meeker, J.D.; Berry, K.; Ehrlich, S.; Perry, M.J.; Cramer, D.W.; Hauser, R. Association of Hexachlorobenzene (HCB), Dichlorodiphenyltrichloroethane (DDT), and Dichlorodiphenyldichloroethylene (DDE) with in Vitro Fertilization (IVF) Outcomes. Environ. Health Perspect. 2012, 120, 316-320. [CrossRef]

31. Meeker, J.D.; Missmer, A.S.; Altshul, L.; Vitonis, A.F.; Ryan, L.; Cramer, D.W.; Hauser, R. Serum and follicular fluid organochlorine concentrations among women undergoing assisted reproduction technologies. Environ. Health 2009, 8, 10-32. [CrossRef] [PubMed]

32. Bloom, M.S.; Fujimoto, V.Y.; Storm, R.; Zhang, L.; Butts, C.D.; Sollohub, D.; Jansing, R.L. Persistent organic pollutants (POPs) in human follicular fluid and in vitro fertilization outcomes, a pilot study. Reprod. Toxicol. 2017, 67, 165-173. [CrossRef] [PubMed]

33. Chiu, Y.-H.; Williams, P.L.; Gillman, M.W.; Gaskins, A.J.; Mínguez-Alarcón, L.; Souter, I.; Toth, T.L.; Ford, J.B.; Hauser, R.; Chavarro, J.E.; et al. Association Between Pesticide Residue Intake from Consumption of Fruits and Vegetables and Pregnancy Outcomes Among Women Undergoing Infertility Treatment with Assisted Reproductive Technology. JAMA Intern. Med. 2018, 178, 17-26. [CrossRef]

34. Jurewicz, J.; Radwan, M.; Wielgomas, B.; Karwacka, A.; Klimowska, A.; Kałużny, P.; Radwan, P.; Hanke, W. Parameters of ovarian reserve in relation to urinary concentrations of parabens. Environ. Health 2020, 19, 1-8. [CrossRef]

35. Whitworth, K.W.; Baird, D.D.; Steiner, A.Z.; Bornman, R.M.S.; Travlos, G.S.; Wilson, R.E.; Longnecker, M.P. Anti-Müllerian Hormone and Lifestyle, Reproductive, and Environmental Factors Among Women in Rural South Africa. Epidemiology 2015, 26, 429-435. [CrossRef]

36. Marettova, E.; Maretta, M.; Legáth, J. Effect of pyrethroids on female genital system. Review. Anim. Reprod. Sci. 2017, 184, 132-138. [CrossRef]

37. Patel, S. Disruption of aromatase homeostasis as the cause of a multiplicity of ailments: A comprehensive review. J. Steroid Biochem. Mol. Biol. 2017, 168, 19-25. [CrossRef]

38. Rattan, S.; Zhou, C.; Chiang, C.; Mahalingam, S.; Brehm, E.; Flaws, J.A. Exposure to endocrine disruptors during adulthood: Consequences for female fertility. J. Endocrinol. 2017, 233, R109-R129. [CrossRef] [PubMed]

39. Sharma, R.K.; Singh, P.; Setia, A.; Sharma, A.K. Insecticides and ovarian functions. Environ. Mol. Mutagen. 2020, 61, 369-392. [CrossRef]

40. Piazza, M.J.; Urbanetz, A.A. Environmental toxins and the impact of other endocrine disrupting chemicals in women's reproductive health. JBRA Assist. Reprod. 2019, 23, 154-164. [CrossRef] [PubMed]

41. Vabre, P.; Gatimel, N.; Moreau, J.; Gayrard, V.; Picard-Hagen, N.; Parinaud, J.; Léandri, R. Environmental pollutants, a possible etiology for premature ovarian insufficiency: A narrative review of animal and human data. Environ. Health 2017, 16, 1-18. [CrossRef]

42. Garry, V.F.; Harkins, M.; Lyubimov, A.; Erickson, L.; Long, L. Reproductive outcomes in the women of the red river valley of the north. I. The spouses of pesticide applicators: Pregnancy loss, age at menarche, and exposures to pesticides. J. Toxicol. Environ. Health Part. A 2002, 65, 769-786. [CrossRef]

43. Naidoo, S.; London, L.; Burdorf, A.; Naidoo, R.; Kromhout, H. Spontaneous miscarriages and infant deaths among female farmers in rural South Africa. Scand. J. Work. Environ. Health 2010, 37, 227-236. [CrossRef] [PubMed]

44. Rahimi, T.; Rafati, F.; Sharifi, H.; Seyedi, F. General and reproductive health outcomes among female greenhouse workers: A comparative study. BMC Women's Health 2020, 20, 103. [CrossRef] [PubMed]

45. Vasiliu, O.; Muttineni, J.; Karmaus, W. In utero exposure to organochlorines and age at menarche. Hum. Reprod. 2004, 19, 1506-1512. [CrossRef]

46. Ye, X.; Pan, W.; Zhao, Y.; Zhao, S.; Zhu, Y.; Liu, W.; Liu, J. Association of pyrethroids exposure with onset of puberty in Chinese girls. Environ. Pollut. 2017, 227, 606-612. [CrossRef]

47. Ouyang, F.; Perry, M.J.; Venners, A.S.; Chen, C.; Wang, B.; Yang, F.; Fang, Z.; Zang, T.; Wang, L.; Xu, X.; et al. Serum DDT, age at menarche, and abnormal menstrual cycle length. Occup. Environ. Med. 2005, 62, 878-884. [CrossRef]

48. Namulanda, G.; Taylor, E.; Maisonet, M.; Barr, D.B.; Flanders, W.D.; Olson, D.; Qualters, J.R.; Vena, J.; Northstone, K.; Naeher, L. In utero exposure to atrazine analytes and early menarche in the Avon Longitudinal Study of Parents and Children Cohort. Environ. Res. 2017, 156, 420-425. [CrossRef] [PubMed]

49. Louis, G.M.B.; Rios, L.I.; McLain, A.; Cooney, M.A.; Kostyniak, P.J.; Sundaram, R. Persistent organochlorine pollutants and menstrual cycle characteristics. Chemosphere 2011, 85, 1742-1748. [CrossRef]

50. Tetsatsi, A.C.M.; Munyali, D.A.; Fozin, G.R.B.; Ngadjui, E.; Wankeu-Nya, M.; Watcho, P. Semen quality among men attending urology services in the Dschang Health District, west Cameroon: A retrospective study on 379 cases. Int. J. Reprod. Biomed. 2020, 18, 121-128. [CrossRef] 
51. Lwin, T.Z.; Than, A.A.; Min, A.Z.; Robson, M.G.; Siriwong, W. Effects of pesticide exposure on reproductivity of male groundnut farmers in Kyauk Kan village, Nyaung-U, Mandalay region, Myanmar. Risk Manag. Health. Policy 2018, 11, 235-241. [CrossRef]

52. Sengupta, P.; Nwagha, U.; Dutta, S.; Krajewska-Kulak, E.; Izuka, E. Evidence for decreasing sperm count in African population from 1965 to 2015. Afr. Health Sci. 2017, 17, 418-427. [CrossRef]

53. Neghab, M.; Momenbella-Fard, M.; Naziaghdam, R.; Salahshour, N.; Kazemi, M.; Alipour, H. The effects of exposure to pesticides on the fecundity status of farm workers resident in a rural region of Fars province, southern Iran. Asian Pac. J. Trop. Biomed. 2014, 4, 324-328. [CrossRef] [PubMed]

54. Cremonese, C.; Piccoli, C.; Pasqualotto, F.; Clapauch, R.; Koifman, R.J.; Koifman, S.; Freire, C. Occupational exposure to pesticides, reproductive hormone levels and sperm quality in young Brazilian men. Reprod. Toxicol. 2017, 67, 174-185. [CrossRef]

55. Miranda-Contreras, L.; Gómez-Pérez, R.; Rojas, G.; Cruz, I.; Berrueta, L.; Salmen, S.; Colmenares, M.; Barreto, S.; Balza, A.; Zavala, L.; et al. Occupational Exposure to Organophosphate and Carbamate Pesticides Affects Sperm Chromatin Integrity and Reproductive Hormone Levels among Venezuelan Farm Workers. J. Occup. Health 2013, 55, 195-203. [CrossRef]

56. Yucra, S.; Rubio, J.; Gasco, M.; Gonzales, C.; Steenland, K.; Gonzales, G.F. Semen Quality and Reproductive Sex Hormone Levels in Peruvian Pesticide Sprayers. Int. J. Occup. Environ. Health 2006, 12, 355-361. [CrossRef]

57. Dhooge, W.; Van Larebeke, N.; Comhaire, F.; Kaufman, J.-M. Reproductive Parameters of Community-Dwelling Men From 2 Regions in Flanders Are Associated With the Consumption of Self-Grown Vegetables. J. Androl. 2007, 28, 836-846. [CrossRef] [PubMed]

58. Yucra, S.; Gasco, M.; Rubio, J.; Gonzales, G.F. Semen quality in Peruvian pesticide applicators: Association between urinary organophosphate metabolites and semen parameters. Environ. Health 2008, 7, 59. [CrossRef]

59. Celik-Ozenci, C.; Tasatargil, A.; Tekcan, M.; Sati, L.; Gungor, E.; Isbir, M.; Usta, M.F.; Akar, M.E.; Erler, F. Effect of abamectin exposure on semen parameters indicative of reduced sperm maturity: A study on farmworkers in Antalya (Turkey). Andrologia 2012, 44, 388-395. [CrossRef] [PubMed]

60. Aguilar-Garduño, C.; Lacasaña, M.; Blanco-Muñoz, J.; Rodríguez-Barranco, M.; Hernández, A.; Bassol, S.; González-Alzaga, B.; Cebrián, M. Changes in male hormone profile after occupational organophosphate exposure. A longitudinal study. Toxicology 2013, 307, 55-65. [CrossRef] [PubMed]

61. Hu, Y.; Zhang, Y.; Vinturache, A.; Wang, Y.; Shi, R.; Chen, L.; Qin, K.; Tian, Y.; Gao, Y. Effects of environmental pyrethroids exposure on semen quality in reproductive-age men in Shanghai, China. Chemosphere 2020, 245, 125580. [CrossRef] [PubMed]

62. Ji, G.; Xia, Y.; Gu, A.; Shi, X.; Long, Y.; Song, L.; Wang, S.; Wang, X. Effects of non-occupational environmental exposure to pyrethroids on semen quality and sperm DNA integrity in Chinese men. Reprod. Toxicol. 2011, 31, 171-176. [CrossRef] [PubMed]

63. Yoshinaga, J.; Imai, K.; Shiraishi, H.; Nozawa, S.; Yoshiike, M.; Mieno, M.N.; Andersson, A.-M.; Iwamoto, T. Pyrethroid insecticide exposure and reproductive hormone levels in healthy Japanese male subjects. Andrology 2014, 2, 416-420. [CrossRef] [PubMed]

64. Imai, K.; Yoshinaga, J.; Yoshikane, M.; Shiraishi, H.; Mieno, M.N.; Yoshiike, M.; Nozawa, S.; Iwamoto, T. Pyrethroid insecticide exposure and semen quality of young Japanese men. Reprod. Toxicol. 2014, 43, 38-44. [CrossRef] [PubMed]

65. Toshima, H.; Suzuki, Y.; Imai, K.; Yoshinaga, J.; Shiraishi, H.; Mizumoto, Y.; Hatakeyama, S.; Onohara, C.; Tokuoka, S. Endocrine disrupting chemicals in urine of Japanese male partners of subfertile couples: A pilot study on exposure and semen quality. Int. J. Hyg. Environ. Health 2012, 215, 502-506. [CrossRef] [PubMed]

66. Radwan, M.; Jurewicz, J.; Wielgomas, B.; Sobala, W.; Piskunowicz, M.; Radwan, P.; Hanke, W. Semen Quality and the Level of Reproductive Hormones After Environmental Exposure to Pyrethroids. J. Occup. Environ. Med. 2014, 56, 1113-1119. [CrossRef] [PubMed]

67. Meeker, J.D.; Barr, D.B.; Hauser, R. Human semen quality and sperm DNA damage in relation to urinary metabolites of pyrethroid insecticides. Hum. Reprod. 2008, 23, 1932-1940. [CrossRef] [PubMed]

68. Young, A.H.; Meeker, J.D.; Martenies, E.S.; Figueroa, I.Z.; Barr, D.B.; Perry, M.J. Environmental exposure to pyrethroids and sperm sex chromosome disomy: A cross-sectional study. Environ. Health 2013, 12, 111. [CrossRef]

69. Pant, N.; Shukla, M.; Upadhyay, A.D.; Chaturvedi, P.K.; Saxena, D.K.; Gupta, Y.K. Association between environmental exposure to p, p'-DDE and lindane and semen quality. Environ. Sci. Pollut. Res. 2014, 21, 11009-11016. [CrossRef]

70. Hauser, R.; Chen, Z.; Pothier, L.; Ryan, L.; Altshul, L. The relationship between human semen parameters and environmental exposure to polychlorinated biphenyls and p,p'-DDE. Environ. Health Perspect. 2003, 111, 1505-1511. [CrossRef] [PubMed]

71. Haugen, T.B.; Tefre, T.; Malm, G.; Jönsson, B.A.; Rylander, L.; Hagmar, L.; Bjørsvik, C.; Henrichsen, T.; Sæther, T.; Figenschau, Y.; et al. Differences in serum levels of CB-153 and p, $\mathrm{p}^{\prime}$-DDE, and reproductive parameters between men living south and north in Norway. Reprod. Toxicol. 2011, 32, 261-267. [CrossRef]

72. Perry, M.J.; Young, H.A.; Grandjean, P.; Halling, J.; Petersen, M.S.; Martenies, S.; Karimi, P.; Weihe, P. Sperm Aneuploidy in Faroese Men with Lifetime Exposure to Dichlorodiphenyldichloroethylene (p,p'-DDE) and Polychlorinated Biphenyl (PCB) Pollutants. Environ. Health Perspect. 2016, 124, 951-956. [CrossRef]

73. Bae, J.; Kim, S.; Barr, D.B.; Louis, G.M.B. Maternal and paternal serum concentrations of persistent organic pollutants and the secondary sex ratio: A population-based preconception cohort study. Environ. Res. 2018, 161, 9-16. [CrossRef]

74. Giwercman, A.; Rylander, L.; Rignell-Hydbom, A.; Jönsson, B.A.; Pedersen, H.S.; Ludwicki, J.K.; Lesovoy, V.; Zvyezday, V.; Spano, M.; Manicardi, G.C.; et al. Androgen receptor gene CAG repeat length as a modifier of the association between persistent organohalogen pollutant exposure markers and semen characteristics. Pharm. Genom. 2007, 17, 391-401. [CrossRef] [PubMed] 
75. Toft, G.; Rignell-Hydbom, A.; Tyrkiel, E.; Shvets, M.; Giwercman, A.; Lindh, C.H.; Pedersen, H.S.; Ludwicki, J.K.; Lesovoy, V.; Hagmar, L.; et al. Semen Quality and Exposure to Persistent Organochlorine Pollutants. Epidemiology 2006, 17, 450-458. [CrossRef]

76. Tiido, T.; Rignell-Hydbom, A.; Jönsson, B.A.; Giwercman, Y.L.; Pedersen, H.S.; Wojtyniak, B.; Ludwicki, J.K.; Lesovoy, V.; Zvyezday, V.; Spano, M.; et al. Impact of PCB andp,p'-DDE Contaminants on Human Sperm Y:X Chromosome Ratio: Studies in Three European Populations and the Inuit Population in Greenland. Environ. Health Perspect. 2006, 114, 718-724. [CrossRef]

77. Stronati, A.; Manicardi, G.C.; Cecati, M.; Bordicchia, M.; Ferrante, L.; Spanò, M.; Toft, G.; Bonde, J.P.; Jönsson, B.A.G.; RignellHydbom, A.; et al. Relationships between sperm DNA fragmentation, sperm apoptotic markers and serum levels of CB-153 and p,p'-DDE in European and Inuit populations. Reproduction 2006, 132, 949-958. [CrossRef] [PubMed]

78. Dziewirska, E.; Radwan, M.; Wielgomas, B.; Klimowska, A.; Radwan, P.; Kałużny, P.; Hanke, W.; Słodki, M.; Jurewicz, J. Human Semen Quality, Sperm DNA Damage, and the Level of Urinary Concentrations of $1 \mathrm{~N}$ and TCPY, the Biomarkers of Nonpersistent Insecticides. Am. J. Men's Health 2018, 13, 1557988318816598. [CrossRef] [PubMed]

79. Swan, S.H. Semen quality in fertile US men in relation to geographical area and pesticide exposure. Int. J. Androl. 2006, 29, 62-68. [CrossRef]

80. Swan, S.H.; Kruse, R.; Liu, F.; Barr, D.B.; Drobnis, E.Z.; Redmon, J.B.; Wang, C.; Brazil, C.; Overstreet, J.W. Study for Future Families Research Group Semen quality in relation to biomarkers of pesticide exposure. Environ. Health Perspect. 2003, 111, 1478-1484. [CrossRef]

81. Luderer, U.; Kesner, J.S.; Fuller, J.M.; Krieg, E.F.; Meadows, J.W.; Tramma, S.L.; Yang, H.; Baker, D. Effects of gestational and lactational exposure to heptachlor epoxide on age at puberty and reproductive function in men and women. Environ. Res. 2013, 121, 84-94. [CrossRef]

82. Mathiesen, L.; Mørck, T.A.; Poulsen, M.S.; Nielsen, J.K.S.; Mose, T.; Long, M.; Bonefeld-Jørgensen, E.; Bossi, R.; Knudsen, L.E. Placental transfer of pesticides studied in human placental perfusion. Basic Clin. Pharmacol. Toxicol. 2020, 127, 505-515. [CrossRef]

83. Fukata, H.; Omori, M.; Osada, H.; Todaka, E.; Mori, C. Necessity to Measure PCBs and Organochlorine Pesticide Concentrations in Human Umbilical Cords for Fetal Exposure Assessment. Environ. Health Perspect. 2005, 113, 297-303. [CrossRef] [PubMed]

84. Vizcaino, E.; Grimalt, J.O.; Somoano, A.F.; Tardon, A. Transport of persistent organic pollutants across the human placenta. Environ. Int. 2014, 65, 107-115. [CrossRef]

85. Yin, S.; Zhang, J.; Guo, F.; Poma, G.; Covaci, A.; Liu, W. Transplacental transfer mechanism of organochlorine pesticides: An in vitro transcellular transport study. Environ. Int. 2020, 135, 105402. [CrossRef]

86. Zhang, X.; Wu, X.; Lei, B.; Jing, Y.; Jiang, Z.; Zhang, X.; Fang, X.; Yu, Y. Transplacental transfer characteristics of organochlorine pesticides in paired maternal and cord sera, and placentas and possible influencing factors. Environ. Pollut. 2018, 233, 446-454. [CrossRef] [PubMed]

87. Holland, N.; Furlong, C.; Bastaki, M.; Richter, R.; Bradman, A.; Huen, K.; Beckman, K.; Eskenazi, B. Paraoxonase Polymorphisms, Haplotypes, and Enzyme Activity in Latino Mothersand Newborns. Environ. Health Perspect. 2006, 114, 985-991. [CrossRef] [PubMed]

88. Wohlfahrt-Veje, C.; Andersen, H.R.; Schmidt, I.M.; Aksglaede, L.; Sørensen, K.; Juul, A.; Jensen, T.K.; Grandjean, P.; Skakkebaek, N.E.; Main, K.M. Early breast development in girls after prenatal exposure to non-persistent pesticides. Int. J. Androl. 2012, 35, 273-282. [CrossRef] [PubMed]

89. Wohlfahrt-Veje, C.; Andersen, H.R.; Jensen, T.K.; Grandjean, P.; Skakkebaek, N.E.; Main, K.M. Smaller genitals at school age in boys whose mothers were exposed to non-persistent pesticides in early pregnancy. Int. J. Androl. 2012, 35, 265-272. [CrossRef] [PubMed]

90. Andersen, H.R.; Schmidt, I.M.; Grandjean, P.; Jensen, T.K.; Budtz-Jørgensen, E.; Kjærstad, M.B.; Bælum, J.; Nielsen, J.B.; Skakkebæk, N.E.; Main, K.M. Impaired Reproductive Development in Sons of Women Occupationally Exposed to Pesticides during Pregnancy. Environ. Health Perspect. 2008, 116, 566-572. [CrossRef]

91. Gaspari, L.; Paris, F.; Jandel, C.; Kalfa, N.; Orsini, M.; Daurès, J.P.; Sultan, C. Prenatal environmental risk factors for genital malformations in a population of 1442 French male newborns: A nested case-control study. Hum. Reprod. 2011, 26, 3155-3162 [CrossRef]

92. Dewan, P.; Jain, V.; Gupta, P.; Banerjee, B.D. Organochlorine pesticide residues in maternal blood, cord blood, placenta, and breastmilk and their relation to birth size. Chemosphere 2013, 90, 1704-1710. [CrossRef]

93. Narduzzi, S.; Fantini, F.; Blasetti, F.; Rantakokko, P.; Kiviranta, H.; Forastiere, F.; Michelozzi, P.; Porta, D. Predictors of BetaHexachlorocyclohexane blood levels among people living close to a chemical plant and an illegal dumping site. Environ. Health 2020, 19, 1-9. [CrossRef]

94. Yu, Y.; Wang, B.; Wang, X.; Wang, R.; Wang, W.; Shen, G.; Shen, H.; Li, W.; Wong, M.; Liu, W.; et al. Hexachlorocyclohexanes (HCHs) in placenta and umbilical cord blood and dietary intake for women in Beijing, China. Environ. Pollut. 2013, 179, 75-80. [CrossRef]

95. Carlson, B.M.; Brudon, M.C. Human Embryology and Developmental Biology; Elsevier: St. Louis, MO, USA, 2019.

96. Choi, S.; Kim, H.-J.; Kim, S.; Choi, G.; Kim, S.; Park, J.; Shim, S.-S.; Lee, I.; Kim, S.; Moon, H.-B.; et al. Current status of organochlorine pesticides (OCPs) and polychlorinated biphenyls (PCBs) exposure among mothers and their babies of KoreaCHECK cohort study. Sci. Total Environ. 2018, 618, 674-681. [CrossRef] [PubMed] 
97. Al-Saleh, I.; Al-Doush, I.; Alsabbaheen, A.; Mohamed, G.E.D.; Rabbah, A. Levels of DDT and its metabolites in placenta, maternal and cord blood and their potential influence on neonatal anthropometric measures. Sci. Total Environ. 2012, 416, 62-74. [CrossRef]

98. Torres-Sanchez, L.; Zepeda, M.; Cebrian, M.E.; Belkind-Gerson, J.; Garcia-Hernandez, R.M.; Belkind-Valdovinos, U.; LópezCarrillo, L. Dichlorodiphenyldichloroethylene exposure during the first trimester of pregnancy alters the anal position in male infants. Ann. New York Acad. Sci. 2008, 1140, 155-162. [CrossRef]

99. Fernandez, M.F.; Olmos, B.; Granada, A.; López-Espinosa, M.J.; Molina-Molina, J.-M.; Fernandez, J.M.; Cruz, M.; Olea-Serrano, F.; Olea, N. Human Exposure to Endocrine-Disrupting Chemicals and Prenatal Risk Factors for Cryptorchidism and Hypospadias: A Nested Case-Control Study. Environ. Health Perspect. 2007, 115 (Suppl. 1), 8-14. [CrossRef]

100. Eskenazi, B.; Rauch, S.A.; Tenerelli, R.; Huen, K.; Holland, N.T.; Lustig, R.H.; Kogut, K.; Bradman, A.; Sjödin, A.; Harley, K.G. In utero and childhood DDT, DDE, PBDE and PCBs exposure and sex hormones in adolescent boys: The CHAMACOS study. Int. J. Hyg. Environ. Health 2017, 220, 364-372. [CrossRef] [PubMed]

101. Vested, A.; Ramlau-Hansen, C.H.; Olsen, S.F.; Bonde, J.P.; Støvring, H.; Kristensen, S.L.; Halldorsson, I.T.; Rantakokko, P.; Kiviranta, H.; Ernst, E.H.; et al. In utero exposure to persistent organochlorine pollutants and reproductive health in the human male. Reproduction 2014, 148, 635-646. [CrossRef] [PubMed]

102. Cohn, A.B.; Cirillo, P.M.; Wolff, M.S.; Schwingl, P.J.; Cohen, R.D.; Sholtz, I.R.; Ferrara, A.; Christianson, E.R.; Berg, B.J.V.D.; Siiteri, P.K. DDT and DDE exposure in mothers and time to pregnancy in daughters. Lancet 2003, 361, 2205-2206. [CrossRef]

103. You, L.; Sar, M.; Bartolucci, E.; Ploch, S.; Whitt, M. Induction of hepatic aromatase by p,p'-DDE in adult male rats. Mol. Cell. Endocrinol. 2001, 178, 207-214. [CrossRef]

104. Massaad, C.; Entezami, F.; Massade, L.; Benahmed, M.; Olivennes, F.; Barouki, R.; Hamamah, S. How can chemical compounds alter human fertility? Eur. J. Obstet. Gynecol. Reprod. Biol. 2002, 100, 127-137. [CrossRef]

105. Mohammed, A.M.; Karttunen, V.; Huuskonen, P.; Huovinen, M.; Auriola, S.; Vähäkangas, K. Transplacental transfer and metabolism of diuron in human placenta. Toxicol. Lett. 2018, 295, 307-313. [CrossRef] [PubMed]

106. Qin, K.; Zhang, Y.; Wang, Y.; Shi, R.; Pan, R.; Yao, Q.; Tian, Y.; Gao, Y. Prenatal organophosphate pesticide exposure and reproductive hormones in cord blood in Shandong, China. Int. J. Hyg. Environ. Health 2020, 225, 113479. [CrossRef] [PubMed]

107. Usmani, K.A.; Hodgson, E.; Rose, R.L. In vitro metabolism of carbofuran by human, mouse, and rat cytochrome P450 and interactions with chlorpyrifos, testosterone, and estradiol. Chem. Interact. 2004, 150, 221-232. [CrossRef]

108. Araki, A.; Miyashita, C.; Mitsui, T.; Goudarzi, H.; Mizutani, F.; Chisaki, Y.; Itoh, S.; Sasaki, S.; Cho, K.; Moriya, K.; et al. Prenatal organochlorine pesticide exposure and the disruption of steroids and reproductive hormones in cord blood: The Hokkaido study. Environ. Int. 2018, 110, 1-13. [CrossRef] [PubMed]

109. Warembourg, C.; Debost-Legrand, A.; Bonvallot, N.; Massart, C.; Garlantézec, R.; Monfort, C.; Gaudreau, E.; Chevrier, C.; Cordier, S. Exposure of pregnant women to persistent organic pollutants and cord sex hormone levels. Hum. Reprod. 2015, 31, 190-198. [CrossRef]

110. Haraux, E.; Tourneux, P.; Kouakam, C.; Stephan-Blanchard, E.; Boudailliez, B.; Leke, A.; Klein, C.; Chardon, K. Isolated hypospadias: The impact of prenatal exposure to pesticides, as determined by meconium analysis. Environ. Int. 2018, 119, 20-25. [CrossRef]

111. Roncati, L.; Piscioli, F.; Pusiol, T. The endocrine disruptors among the environmental risk factors for stillbirth. Sci. Total. Environ. 2016, 563-564, 1086-1087. [CrossRef]

112. Sagiv, S.K.; Bruno, J.L.; Baker, J.M.; Palzes, V.; Kogut, K.; Rauch, S.; Gunier, R.; Mora, A.M.; Reiss, A.L.; Eskenazi, B. Prenatal exposure to organophosphate pesticides and functional neuroimaging in adolescents living in proximity to pesticide application. Proc. Natl. Acad. Sci. USA 2019, 116, 18347-18356. [CrossRef]

113. Hood, E. Are EDCs Blurring Issues of Gender? Environ. Health Perspect. 2005, 113, A670-A677. [CrossRef]

114. Teodoro, M.; Briguglio, G.; Fenga, C.; Costa, C. Genetic polymorphisms as determinants of pesticide toxicity: Recent advances. Toxicol. Rep. 2019, 6, 564-570. [CrossRef]

115. Mackness, M.; Mackness, B. Human paraoxonase-1 (PON1): Gene structure and expression, promiscuous activities and multiple physiological roles. Gene 2015, 567, 12-21. [CrossRef]

116. Costa, L.G.; Cole, T.B.; Furlong, C.E. Polymorphisms of Paraoxonase (PON1) and Their Significance in Clinical Toxicology of Organophosphates. J. Toxicol. Clin. Toxicol. 2003, 41,37-45. [CrossRef]

117. Mackness, B.; Durrington, P.; Povey, A.; Thomson, S.; Dippnall, M.; Mackness, M.; Smith, T.; Cherry, N. Paraoxonase and susceptibility to organophosphorus poisoning in farmers dipping sheep. Pharmacogenetics 2003, 13, 81-88. [CrossRef]

118. Coombes, R.H.; Meek, E.C.; Dail, M.B.; Chambers, H.W.; Chambers, J.E. Human paraoxonase 1 hydrolysis of nanomolar chlorpyrifos-oxon concentrations is unaffected by phenotype or Q192R genotype. Toxicol. Lett. 2014, 230, 57-61. [CrossRef] [PubMed]

119. Declerck, K.; Remy, S.; Wohlfahrt-Veje, C.; Main, K.M.; Van Camp, G.; Schoeters, G.; Berghe, W.V.; Andersen, H.R. Interaction between prenatal pesticide exposure and a common polymorphism in the PON1 gene on DNA methylation in genes associated with cardio-metabolic disease risk-An exploratory study. Clin. Epigenet. 2017, 9, 35. [CrossRef]

120. Leviev, I.; James, R.W. Promoter polymorphisms of human paraoxonase PON1 gene and serum paraoxonase activities and concentrations. Arter. Thromb. Vasc. Biol. 2000, 20, 516-521. [CrossRef]

121. Brophy, V.H.; Hastings, M.D.; Clendenning, J.B.; Richter, R.J.; Jarvik, G.P.; Furlong, C.E. Polymorphisms in the human paraoxonase (PON1) promoter. Pharmacogenetics 2001, 11, 77-84. [CrossRef] [PubMed] 
122. Davies, H.G.; Richter, R.J.; Keifer, M.; Broomfield, C.A.; Sowalla, J.; Furlong, C.E. The effect of the human serum paraoxonase polymorphism is reversed with diazoxon, soman and sarin. Nat. Genet. 1996, 14, 334-336. [CrossRef]

123. Moreno-Banda, G.; Blanco-Muñoz, J.; Lacasaña, M.; Rothenberg, S.; Aguilar-Garduño, C.; Gamboa, R.; Pérez-Méndez, O. Maternal exposure to floricultural work during pregnancy, PON1 Q192R polymorphisms and the risk of low birth weight. Sci. Total. Environ. 2009, 407, 5478-5485. [CrossRef]

124. Berkowitz, G.S.; Wetmur, J.G.; Birman-Deych, E.; Obel, J.; Lapinski, R.H.; Godbold, J.H.; Holzman, I.R.; Wolff, M.S. In utero pesticide exposure, maternal paraoxonase activity, and head circumference. Environ. Health Perspect. 2004, 112, 388-391. [CrossRef] [PubMed]

125. Engel, S.M.; Wetmur, J.; Chen, J.; Zhu, C.; Barr, D.B.; Canfield, R.L.; Wolff, M.S. Prenatal Exposure to Organophosphates, Paraoxonase 1, and Cognitive Development in Childhood. Environ. Health Perspect. 2011, 119, 1182-1188. [CrossRef] [PubMed]

126. Harley, K.G.; Huen, K.; Schall, R.A.; Holland, N.T.; Bradman, A.; Barr, D.B.; Eskenazi, B. Association of Organophosphate Pesticide Exposure and Paraoxonase with Birth Outcome in Mexican-American Women. PLoS ONE 2011, 6, e23923. [CrossRef]

127. Cole, T.B.; Jampsa, R.L.; Walter, B.J.; Arndt, T.L.; Richter, R.J.; Shih, D.M.; Tward, A.; Lusis, A.J.; Jack, R.M.; Costa, L.G.; et al. Expression of human paraoxonase (PON1) during development. Pharmacogenetics 2003, 13, 357-364. [CrossRef]

128. Furlong, C.E.; Holland, N.; Richter, R.J.; Bradman, A.; Ho, A.; Eskenazi, B. PON1 status of farmworker mothers and children as a predictor of organophosphate sensitivity. Pharm. Genom. 2006, 16, 183-190. [CrossRef]

129. Chen, J.; Kumar, M.; Chan, W.; Berkowitz, G.; Wetmur, J.G. Increased influence of genetic variation on PON1 activity in neonates. Environ. Health Perspect. 2003, 111, 1403-1409. [CrossRef]

130. Andersen, H.R.; Wohlfahrt-Veje, C.; Dalgård, C.; Christiansen, L.; Main, K.M.; Nellemann, C.; Murata, K.; Jensen, T.K.; Skakkebæk, N.E.; Grandjean, P. Paraoxonase 1 Polymorphism and Prenatal Pesticide Exposure Associated with Adverse Cardiovascular Risk Profiles at School Age. PLoS ONE 2012, 7, e36830. [CrossRef]

131. Jørgensen, A.; Nellemann, C.; Wohlfahrt-Veje, C.; Jensen, T.K.; Main, K.M.; Andersen, H.R. Interaction between paraoxonase 1 polymorphism and prenatal pesticide exposure on metabolic markers in children using a multiplex approach. Reprod. Toxicol. 2015, 51, 22-30. [CrossRef]

132. Tinggaard, J.; Wohlfahrt-Veje, C.; Husby, S.; Christiansen, L.; Skakkebaek, N.E.; Jensen, T.K.; Grandjean, P.; Main, K.M.; Andersen, H.R.; Skakkebæk, N.E. Prenatal pesticide exposure andPON1genotype associated with adolescent body fat distribution evaluated by dual X-ray absorptiometry (DXA). Andrology 2016, 4, 735-744. [CrossRef] [PubMed]

133. Padungtod, C.; Niu, T.; Wang, Z.; Savitz, D.A.; Christiani, D.C.; Ryan, L.M.; Xu, X. Paraoxonase polymorphism and its effect on male reproductive outcomes among Chinese pesticide factory workers. Am. J. Ind. Med. 1999, 36, 379-387. [CrossRef]

134. Pérez-Herrera, N.; Polanco-Minaya, H.; Salazar-Arredondo, E.; Solís-Heredia, M.; Hernández-Ochoa, I.; Rojas-García, E.; Alvarado-Mejía, J.; Borja-Aburto, V.; Quintanilla-Vega, B. PON1Q192R genetic polymorphism modifies organophosphorous pesticide effects on semen quality and DNA integrity in agricultural workers from southern Mexico. Toxicol. Appl. Pharmacol. 2008, 230, 261-268. [CrossRef] [PubMed]

135. Cherry, N.; Mackness, M.; Durrington, P.; Povery, A.; Dippnall, M.; Smith, T.; Mackness, B. Paraoxonase (PON1) polymorphisms in farmers attributing ill health to sheep dip. Lancet 2002, 359, 763-764. [CrossRef]

136. Lee, B.W.; London, L.; Paulauskis, J.; Myers, J.; Christiani, D.C. Association Between Human Paraoxonase Gene Polymorphism and Chronic Symptoms in Pesticide-Exposed Workers. J. Occup. Environ. Med. 2003, 45, 118-122. [CrossRef]

137. Cooney, M.A.; Louis, G.M.B.; Sundaram, R.; McGuiness, B.M.; Lynch, C.D. Validity of Self-Reported Time to Pregnancy. Epidemiology 2009, 20, 56-59. [CrossRef] [PubMed]

138. Olsen, J. Design options and sources of bias in time-to-pregnancy studies. Scand. J. Work. Environ. Health 1999, 25 (Suppl. 1), 5-7. [PubMed]

139. Bloom, M.S.; Buck-Louis, G.M.; Schisterman, E.; Kostyniak, P.J.; Vena, J.E. Changes in maternal serum chlorinated pesticide concentrations across critical windows of human reproduction and development. Environ. Res. 2009, 109, 93-100. [CrossRef]

140. Scacchi, R.; Corbo, R.M.; Rickards, O.; De Stefano, G.F. New data on the world distribution of paraoxonase (PON1 Gln $192->$ Arg) gene frequencies. Hum. Biol. 2003, 75, 365-373. [CrossRef]

141. Kim, K.; Bloom, M.S.; Fujimoto, V.Y.; Browne, R.W. Associations between PON1 enzyme activities in human ovarian follicular fluid and serum specimens. PLOS ONE 2017, 12, e0172193. [CrossRef]

142. Ali, S.M.; Chia, S.E. Interethnic variability of plasma paraoxonase (PON1) activity towards organophosphates and PON1 polymorphisms among Asian populations-A short review. Ind. Health 2008, 46, 309-317. [CrossRef]

143. Rauh, V.A.; Perera, F.P.; Horton, M.K.; Whyatt, R.M.; Bansal, R.; Hao, X.; Liu, J.; Barr, D.B.; Slotkin, T.A.; Peterson, B.S. Brain anomalies in children exposed prenatally to a common organophosphate pesticide. Proc. Natl. Acad. Sci. USA 2012, 109, 7871-7876. [CrossRef]

144. Salvador-Oliván, J.A.; Marco-Cuenca, G.; Arquero-Avilés, R. Errors in search strategies used in systematic reviews and their effects on information retrieval. J. Med. Libr. Assoc. 2019, 107, 210-221. [CrossRef] [PubMed]

145. van Weijen, D. The Language of (Future) Scientific Communication. Available online: https://www.researchtrends.com/issue-31 -november-2012/the-language-of-future-scientific-communication/ (accessed on 6 June 2021).

146. Di Bitetti, M.S.; Ferreras, J.A. Publish (in English) or perish: The effect on citation rate of using languages other than English in scientific publications. Ambio 2016, 46, 121-127. [CrossRef] [PubMed] 
147. Ohlander, J.; Fuhrimann, S.; Basinas, I.; Cherrie, J.W.; Galea, K.S.; Povey, A.C.; Van Tongeren, M.; Harding, A.-H.; Jones, K.; Vermeulen, R.; et al. Systematic review of methods used to assess exposure to pesticides in occupational epidemiology studies, 1993-2017. Occup. Environ. Med. 2020, 77, 357-367. [CrossRef] [PubMed]

148. Jones, K.; Basinas, I.; Kromhout, H.; van Tongeren, M.; Harding, A.-H.; Cherrie, J.W.; Povey, A.; Ahmad, Z.N.S.; Fuhrimann, S.; Ohlander, J.; et al. Improving Exposure Assessment Methodologies for Epidemiological Studies on Pesticides: Study Protocol. JMIR Res. Protoc. 2020, 9, e16448. [CrossRef] [PubMed] 